University of Nebraska - Lincoln

DigitalCommons@University of Nebraska - Lincoln

\title{
The floodplain food web mosaic: a study of its importance to salmon and steelhead with implications for their recovery
}

\author{
J. Ryan Bellmore \\ U.S. Geological Survey, jbellmore@usgs.gov \\ Colden V. Baxter \\ Idaho State University \\ Kyle Martens \\ U.S. Geological Survey, kyle.martens@huskers.unl.edu \\ Patrick J. Connolly \\ U.S. Geological Survey
}

Follow this and additional works at: https://digitalcommons.unl.edu/usgsstaffpub

Part of the Geology Commons, Oceanography and Atmospheric Sciences and Meteorology Commons, Other Earth Sciences Commons, and the Other Environmental Sciences Commons

Bellmore, J. Ryan; Baxter, Colden V.; Martens, Kyle; and Connolly, Patrick J., "The floodplain food web mosaic: a study of its importance to salmon and steelhead with implications for their recovery" (2013). USGS Staff -- Published Research. 699.

https://digitalcommons.unl.edu/usgsstaffpub/699

This Article is brought to you for free and open access by the US Geological Survey at DigitalCommons@University of Nebraska - Lincoln. It has been accepted for inclusion in USGS Staff -- Published Research by an authorized administrator of DigitalCommons@University of Nebraska - Lincoln. 


\title{
The floodplain food web mosaic: a study of its importance to salmon and steelhead with implications for their recovery
}

\author{
J. Ryan Bellmore, ${ }^{1,2,3}$ Colden V. Baxter, ${ }^{2}$ Kyle Martens ${ }^{1}$ and Patrick J. Connolly ${ }^{1}$ \\ ${ }^{1}$ U.S. Geological Survey, Western Fisheries Research Center, Columbia River Research Laboratory, Cook, Washington 98605 USA \\ ${ }^{2}$ Department of Biological Sciences, Idaho State University, Pocatello, Idaho 83209 USA
}

\begin{abstract}
Although numerous studies have attempted to place species of interest within the context of food webs, such efforts have generally occurred at small scales or disregard potentially important spatial heterogeneity. If food web approaches are to be employed to manage species, studies are needed that evaluate the multiple habitats and associated webs of interactions in which these species participate. Here, we quantify the food webs that sustain rearing salmon and steelhead within a floodplain landscape of the Methow River, Washington, USA, a location where restoration has been proposed to restore side channels in an attempt to recover anadromous fishes. We combined year-long measures of production, food demand, and diet composition for the fish assemblage with estimates of invertebrate prey productivity to quantify food webs within the main channel and five different, intact, side channels; ranging from channels that remained connected to the main channel at low flow to those reduced to floodplain ponds. Although we found that habitats within the floodplain had similar invertebrate prey production, these habitats hosted different local food webs. In the main channel, $95 \%$ of total prey consumption flowed to fishes that are not the target of proposed restoration. These fishes consumed $64 \%$ and $47 \%$ of the prey resources that were found to be important to fueling chinook and steelhead production in the main channel, respectively. Conversely, in side channels, a greater proportion of prey was consumed by anadromous salmonids. As a result, carrying capacity estimates based on food were $251 \%$ higher, on average, for anadromous salmonids in side channels than the main channel. However, salmon and steelhead production was generally well below estimated capacity in both the main and side channels, suggesting these habitats are under-seeded with respect to food, and that much larger populations could be supported. Overall, this study demonstrates that floodplain heterogeneity is associated with the occurrence of a mosaic of food webs, all of which were utilized by anadromous salmonids, and all of which may be important to their recovery and persistence. In the long term, these and other fishes would likely benefit from restoring the processes that maintain floodplain complexity.
\end{abstract}

Key words: ecosystem ecology; floodplains; food webs; salmon; secondary production; side channels; steelhead.

\section{INTRODUCTION}

Food webs describe the pathways by which energy and materials move through ecosystems, and provide insight into the complex, multispecies assemblages within which organisms of interest grow, survive, and reproduce (Elton 1927, Polis and Winemiller 1996). Although most natural resource science has traditionally focused on the population dynamics of single species of interest (Pikitch et al. 2004), the importance of food webs is now well recognized, and there are numerous examples of studies that describe the food webs within which focal species occur (e.g., Christensen and Pauly 1993, Vander Zanden et al. 2003). However, most of these studies have been conducted at small scales, and

Manuscript received 17 May 2012; revised 2 August 2012; accepted 16 August 2012. Corresponding Editor (ad hoc): P. A. Bisson.

${ }^{3}$ E-mail: jbellmore@usgs.gov do not investigate the spatial heterogeneity of landscapes within which species are embedded (Woodward and Hildrew 2002). The subdiscipline of landscape ecology, on the other hand, focuses on spatial heterogeneity and its consequences for organisms at larger spatial scales (Wiens 2002), but has rarely addressed food webs. Instead of describing food webs for single habitats, or aggregating food web information over heterogeneous landscapes, it may be important to bridge the gap between food web and landscape ecology (Polis et al. 2004) by studying food webs across the variety of different habitats used by species of interest.

River floodplains are considered among the most biophysically complex and diverse landscapes on earth (Bayley 1995, Tockner and Stanford 2002). Flood pulses that redistribute sediment and organic matter create a dynamic mosaic of aquatic and terrestrial habitat in floodplains (Junk et al. 1989, Stanford et al. 2005). In the context of natural resource management, 


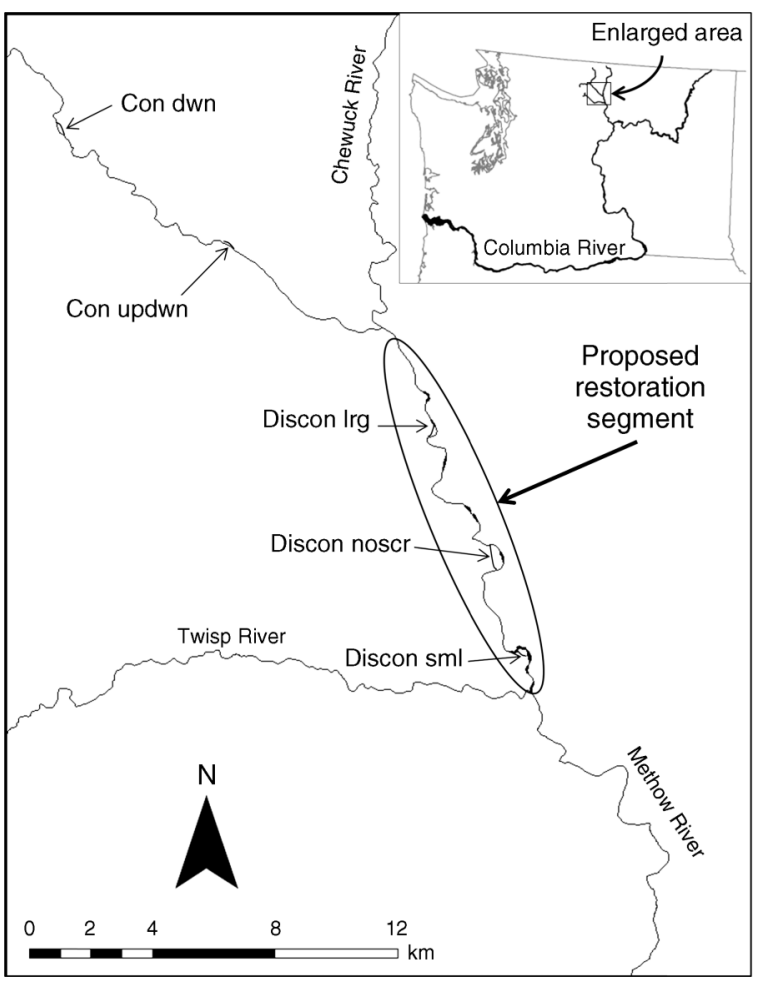

FIG. 1. Map of the Methow River showing the location of side channel habitats and the proposed habitat restoration segment. The inset shows the location of the Methow River in Washington State, USA. Side channel habitats are described in Methods: Study site and design.

the structure of food webs in these different habitats may be important to sustaining species of interest (Winemiller 2005). Unfortunately, many river-floodplain systems have been severely altered by human disturbance, which has constrained the physical processes that create and maintain habitat heterogeneity in floodplains (Tockner and Stanford 2002). This degradation, coupled with the desire to recover and preserve species of concern, has resulted in increasing numbers of habitat restoration projects aimed at floodplain reconnection (Bernhardt et al. 2005). Although prerestoration assessments are now commonly conducted to evaluate the potential for these efforts to succeed (e.g., Beechie et al. 2008), such studies are generally focused exclusively on physical habitat conditions (Wipfli and Baxter 2010, NPCC 2011). The application of food web approaches in pre-restoration studies is often overlooked, except in instances where food webs are being directly manipulated (e.g., nutrient additions [Kohler et al. 2012], predator removal/addition [Carpenter et al. 1985]). In the case of physical habitat restoration (e.g., floodplain reconnection), studies are needed that not only evaluate how restoration will impact the quantity, quality, and diversity of physical habitats, but also how these changes will influence the flows of energy that sustain the species restoration is often aimed at recovering.

In the Pacific Northwest of North America, floodplain restoration is often aimed at the recovery of threatened and endangered Pacific salmon and steelhead (Oncorhynchus spp.; Roni et al. 2002). Although anadromous salmonids typically utilize many environments during their complex life cycle (ocean, estuary, large rivers, and headwaters), floodplains are targeted because they are thought to contain important spawning and rearing habitats for these fish. For example, floodplains have been shown to have more microhabitats (substrate, flow, depth, and temperature combinations) suitable for spawning and egg deposition (Montgomery et al. 1999, Isaak and Thurow 2006). Furthermore, floodplain side channels are thought to be excellent nurseries for juvenile fish, providing conditions favorable for growth, such as lower water velocity, moderated water temperature, and enhanced food availability (Beechie et al. 1994, Sommer et al. 2001, Ebersole et al. 2003, Jeffres et al. 2008). In fact, numerous floodplain restoration projects are specifically targeted at reconnecting and/or recreating side channels to increase rearing capacity for juvenile fishes (e.g., Richards et al. 1992, Bellmore et al. 2012). That said, floodplain habitats are very diverse (e.g., ranging from large, highly connected channels to small, more isolated channels), and are likely to contain food webs that are distinct from one another (Winemiller 2005). Understanding how food webs vary across the floodplain habitat mosaic is important, not only for evaluating the value of individual habitats to salmon and steelhead, but also for assessing how overall landscape heterogeneity influences their populations.

In this study, we apply food web and ecosystem approaches to investigate the mosaic of floodplain habitats utilized by rearing salmon and steelhead in the Methow River, Washington, USA (Fig. 1). As in the case of many rivers throughout the Pacific Northwest, floodplain reconnection has been identified as a priority for recovery of anadromous fishes in the Methow, and pre-restoration assessments are needed to evaluate the potential for proposed restoration to positively affect target species. We combined year-long measures of production, food demand, and diet composition for the entire fish assemblage with estimates of invertebrate prey productivity, to quantify food webs within the main channel and five different, intact side channels; ranging from channels that remained connected to the main channel at low flow to those reduced to isolated floodplain ponds. Together, this combination of food web and ecosystem production-budget measurements allowed us to (1) elucidate dominant pathways of material flow in different floodplain habitats, (2) assess the potential for food limitation of populations of rearing chinook salmon and steelhead, (3) evaluate the potential for exploitative competition for food between target and nontarget fishes, and (4) quantify the relative 
importance of different habitats to sustaining juvenile salmon and steelhead production. Overall, the results of this study highlight the importance of utilizing more holistic food web approaches to understand the role of landscape heterogeneity in the ecology of species of conservation and management concern.

\section{Methods \\ Study site and design}

The Methow River is a fifth-order tributary (4662 $\mathrm{km}^{2}$ ) of the Columbia River, located in north-central Washington, USA (Fig. 1). The headwaters drain east and south from an elevation of $1700 \mathrm{~m}$ in the Cascade Mountains, to $240 \mathrm{~m}$ at the confluence with the Columbia River. A majority of the precipitation falls in the winter in the form of snow. The hydrograph of the Methow River is typical of snow-melt-dominated systems, with peak flows occurring in May and June, and peak discharges often exceeding $300 \mathrm{~m}^{3} / \mathrm{s}$ at the river mouth. Mean annual discharge for the period of record (1959-2012) is $43 \mathrm{~m}^{3} / \mathrm{s}$, with a base flow of $5 \mathrm{~m}^{3} / \mathrm{s}$ (USGS discharge data). Forests, composed primarily of Douglas-fir (Pseudotsuga menziesii) and pine (Pinus spp.), cover much of the basin, with shrub-steppe communities common at elevations less than $1200 \mathrm{~m}$. Floodplain valley bottoms in the lower river are dominated by black cottonwood (Populus trichocarpa) and aspen ( $P$. tremuloides).

Prior to European settlement, the Methow River supported large runs of chinook salmon (Oncorhynchus tshawytscha), coho salmon (O. kisutch), and steelhead (O. mykiss) (Mullan et al. 1992). Today, runs of anadromous fish have been significantly depressed by a history of dams and impoundments, water diversions, overfishing, exotic species, and habitat degradation. Currently, spring chinook salmon are listed as endangered and summer steelhead as threatened under the Endangered Species Act (ESA). Coho salmon, which were extirpated in the 1920s, have recently been reintroduced, and small numbers have begun to spawn naturally in the Methow. The resident (non-anadromous) fish assemblage of the Methow includes westslope cutthroat trout (O. clarkia lewisi; hereafter referred to as cutthroat), bull trout (Salvelinus confluentus), rainbow trout (O. mykiss), mountain whitefish (Prosopium williamsoni; hereafter referred to as whitefish), longnose dace (Rhinichthys cataractae; hereafter referred to as dace), bridgelip sucker (Catostomus columbianus; hereafter referred to as sucker), and several species of sculpin (Cottus bairdi, C. confusus, and C. rhotheus; hereafter referred to as sculpin). Other fish species present in the Methow are native Pacific lamprey (Lampetra tridentata) and nonnative brook trout ( $S$. fontinalis), brown bullhead (Ameiurus nebulosus), and smallmouth bass (Micropterus dolomieu). However, these species were rare at the time and place of our study, and were not included in our analyses. In addition, because we could not distinguish between anadromous and resident rainbow trout, hereafter we refer to all rainbow trout as steelhead.

The floodplain segment that has been targeted for restoration in the Methow is located between the confluences with the Twisp and Chewuch Rivers (Fig. 1). This $13.5 \mathrm{~km}$ long segment has been developed for agricultural and residential use, and sections have been diked (i.e., rip-rapped banks) to protect private property, leading to the disconnection of the river from the floodplain (see Plate 1). Despite this degradation, large portions of the river and associated floodplain remain relatively intact, and numerous side channel complexes still exist.

To evaluate the importance of different floodplain habitats to juvenile chinook salmon and steelhead, we quantified fish and invertebrate prey production, and constructed quantitative flow food webs in six different floodplain aquatic habitats. These six habitats included the main channel of the restoration segment, and five intact side channels, which varied naturally in their level of hydrologic connectivity to the main channel. Three of the five side channels were located within the restoration segment and two were located upstream (Fig. 1). During spring runoff (April-June), all side channels had both an upstream and downstream surface water connection to the main channel, allowing aquatic organisms, including juvenile salmon and steelhead, to move between side channels and the main channel. As flows receded, three of the side channels became disconnected from the main channel and were eventually reduced to one or more isolated pools, whereas two side channels retained some level of surface water connection to the main channel year-round (see Appendix A for habitat photographs). For convenience, we refer to the five side channels according to their level of hydrologic connectivity with the main channel under low-flow conditions during the period of our study (2009-2010): con updwn refers to the side channel that retained both up and downstream surface water connections; con $d w n$ is the side channel with only a downstream surface water connection; discon $\operatorname{lrg}$ is disconnected from the main channel but retained one relatively large pool; discon sml is disconnected and mainly represented by one small pool; and discon noscr is disconnected with large pools, but in contrast to the other side channels, its bed was not scoured by high flows during the study period. Together, these five side channels, along with the main channel, represented a range of hydrologic conditions (i.e., connectivity and disturbance history), physical character (e.g., temperature) and habitat dimensions (Table 1).

\section{Habitat measurements}

Habitat surveys of each side channel were conducted approximately monthly during 2009 and 2010. Surveys measured the area (lengths and widths), average and maximum depth, and proportion of different channel units (e.g., pools, riffles, glides) present. The area and 
TABLE 1. Habitat characteristics of the six habitats sampled in this study for 2009 .

\begin{tabular}{|c|c|c|c|c|c|c|c|c|c|c|}
\hline \multirow[b]{2}{*}{ Habitat type } & \multirow[b]{2}{*}{ Habitat name } & \multicolumn{2}{|c|}{ "Surface water connection? } & \multirow[b]{2}{*}{ Bed scour? } & \multicolumn{2}{|c|}{ Habitat area $\left(\mathrm{m}^{2}\right)$} & \multirow[b]{2}{*}{ Length $(\mathrm{m})$} & \multicolumn{3}{|c|}{ Temperature $\left({ }^{\circ} \mathrm{C}\right)$} \\
\hline & & Downstream & Upstream & & High flow & Base flow & & Summer & Fall & Winter \\
\hline Main channel & Main ch & $\mathrm{Y}$ & $\mathrm{Y}$ & $\mathrm{Y}$ & & 760000 & 17000 & 15.2 & & 4.2 \\
\hline Side channel & Con updwn & $\mathrm{Y}$ & $\mathrm{Y}$ & $\mathrm{Y}$ & 3550 & 2875 & 310 & 13.6 & 6.9 & 5.4 \\
\hline Side channel & Con dwn & $\mathrm{Y}$ & $\mathrm{N}$ & $\mathrm{Y}$ & 13975 & 6325 & 690 & 11.4 & 6.7 & 5.1 \\
\hline Side channel & Discon lrg & $\mathrm{N}$ & $\mathrm{N}$ & $\mathrm{Y}$ & 6425 & 2200 & 490 & 14.9 & 7.4 & 5.4 \\
\hline Side channel & Discon sml & $\mathrm{N}$ & $\mathrm{N}$ & $\mathrm{Y}$ & 7500 & 1100 & 605 & 16.1 & 4.7 & \\
\hline Side channel & Discon noscr & $\mathrm{N}$ & $\mathrm{N}$ & $\mathrm{N}$ & 6150 & 3400 & 582 & 13.2 & 4.9 & 1.4 \\
\hline
\end{tabular}

Notes: Characteristics evaluated are: whether or not habitats had surface water hydrological connectivity during low flows; whether or not the habitats were scoured during high flows; approximate habitat area during high and low flows; habitat length during high flows when all habitats were fully connected to the main channel; and average daily water temperatures for summer, fall, and winter. Y stands for yes, and N stands for no. Empty cells indicate that no data were available.

proportion of different channel units present in the main channel were determined from a single survey completed in summer 2009. Water temperatures were recorded for the main channel and each side channel during summer, fall and winter (except in a few cases; see Table 1) using Onset HOBO data loggers (Pocasset, Massachusetts, USA). Water temperature was not monitored during the spring due to high flows.

\section{Invertebrate food base productivity}

We sampled benthic substrates for invertebrates in the main channel and each side channel in June, August, and October of 2009 and March 2010. June sampling occurred while all side channels were still connected to the main channel. On each date, we collected at least three replicate samples from each habitat, and in August we collected five samples. We collected all benthic samples using a modified Surber sampler $(250-\mu \mathrm{m}$ mesh) that was attached to a shovel handle, and which had a sample quadrat larger than traditionally sized Surber samplers $\left(0.26 \mathrm{~m}^{2}\right.$ compared to $0.096 \mathrm{~m}^{2}$ ). One person held the sampler in place, while another disturbed substrate to a depth of $\sim 10$ $\mathrm{cm}$. Each of our replicate samples represented a composite of several subsamples ( $n=3-11$ subsamples), which we collected in proportion to the different channel unit types present (e.g., riffles, pools) within each habitat. When subsamples were combined, each replicate sample incorporated the perceived variation within each habitat, for each sampling date. As a result of this subsampling scheme, and the larger size of our Surber sampler, each replicate sample in this study represented $0.8-2.9 \mathrm{~m}^{2}$ of benthic area, which is at least eight times greater than the benthic area sampled from a single sample using a traditional Surber sampler. Although we sacrificed the ability to quantify variation within each habitat (i.e., between channel unit types) using this approach, it allowed us to better represent the habitat as a whole, without significantly inflating the total number of samples to be processed. Although we acknowledge that it would have been ideal to have a larger sample size, we were limited by the amount of time necessary to process each sample in the lab. We elutriated all samples through a $250-\mu \mathrm{m}$ sieve and removed as much of the inorganic material as possible. The remaining sample was preserved in $95 \%$ ethanol. In the lab, a two-phased sorting approach was utilized (after Vinson and Hawkins 1996). In the first phase, all large invertebrates $(\geq 10 \mathrm{~mm})$ were removed from the sample. In the second phase, successive subsamples were removed and sorted at $10 \times$ magnification until at least 500 individuals were picked. We identified all invertebrates to genus or species, except for Chironomidae, which we split into Tanypodinae and nonTanypodinae. All invertebrates were then dried at $60^{\circ} \mathrm{C}$ for 24 hours and weighed. We used these seasonal data to calculate the mean annual biomass of each taxon for each habitat. We calculated $95 \%$ confidence intervals for mean biomass estimates via bootstrapping (see Benke and Huryn 2006), whereby the biomass of each taxon for each habitat on each date was resampled with replacement 10000 times to generate 10000 separate estimates of mean annual biomass.

In order to estimate invertebrate secondary production, we collected a single composite sample from the main channel and one side channel (discon noscr) at approximately monthly intervals (June 2009 to June 2010). We processed these samples following the same methods described above, except that we measured the lengths of all individual invertebrates to the nearest 0.5 $\mathrm{mm}$. The biomass of each taxon was then calculated using literature-based length-mass relationships (Benke et al. 1999). We then estimated secondary production for all common taxa using the size-frequency method, corrected for our best estimate of cohort production interval from size-frequency data (see Benke and Huryn 2006). Two additional estimates of non-Tanypodinae chironomid production were calculated using the instantaneous growth method, based on the size- and temperature-specific equations of Huryn (1990) and Walther et al. (2006). The three separate estimates of non-Tanypodinae chironomid production were averaged for use in this study. We calculated production to biomass $(P: B)$ ratios by dividing production in each of these habitats by the average taxon biomass for that habitat. Production at all habitats was then calculated 
by multiplying $P: B$ estimates by mean annual biomass of each taxon within each habitat. To account for potential differences in invertebrate growth rates between connected and disconnected habitats, $P: B$ estimates from the discon noscr habitat were applied to all disconnected side channels (discon lrg, discon sml, discon noscr), whereas $P: B$ values from the main channel were applied to connected side channels (Con updwn, Con dwn) and the main channel. Of course, $P: B$ values for similar taxa could differ across all habitat types. However, in terms of estimating total invertebrate secondary production, we assumed that uncertainty associated with taxon-specific $P: B$ values would be relatively minor compared to measured differences (and associated uncertainty) in the composition and biomass of invertebrates across habitats. For rare taxa, we estimated secondary production using published annual $P: B$ ratios. When available, we used $P: B$ ratios from nearby production studies (Gaines et al. 1992, Robinson and Minshall 1998). Total annual benthic invertebrate production was calculated as the sum of taxon specific production.

We measured terrestrial invertebrate flux to the main channel and each side channel monthly (July, August, September) during summer 2009. We placed 10-12 pan traps $\left(0.21 \mathrm{~m}^{2}\right)$ at the wetted edge of the stream at each habitat. Pans were distributed in proportion to the presence of different riparian vegetation types (e.g., willow, cottonwood, conifer), because invertebrate inputs are known to vary with riparian vegetation (Baxter et al. 2005). Traps were filled with approximately $5 \mathrm{~cm}$ of water and a few drops of biodegradable soap to reduce water surface tension. After collecting for three days, invertebrates were removed with dip nets $(500-\mu \mathrm{m}$ mesh). In the lab, we sorted samples under a dissecting scope to remove aquatic taxa. The remaining terrestrial taxa were identified to order, dried at $60^{\circ} \mathrm{C}$ for 24 hours and weighed. We calculated total inputs by multiplying average daily fluxes by the number of days in each month.

\section{Fish abundance, biomass, and production}

We estimated the abundance of all but the rarest members of the fish assemblage using a combination of snorkeling and electrofishing. In side channels, the abundance of all salmonids was calculated seasonally (June, August, and October 2009 and March 2010), using the removal-depletion method (White et al. 1982). Block nets were placed at the upstream and downstream of individual channel units (e.g., riffles, pools, glides) within each side channel, and multiple electrofishing passes were completed until an adequate depletion was achieved (following Connolly 1996). Mark-recapture electrofishing was utilized in channel units that were too wide and/or deep to allow for adequate depletions. In channel units that were too deep for electrofishing, fish abundance was estimated with snorkeling. Captured fish were measured for length and mass, and implanted with a passive integrated transponder (PIT) tag, to allow for later detection of previously captured fish. Although these surveys were targeted at salmonids, the numbers of non-salmonids (dace, sculpin, and sucker) were also recorded, and several individuals of each species were captured to obtain lengths and masses. To estimate the abundance of non-salmonids, we first calculated the capture efficiency for the first pass of fishing surveys, obtained by dividing the number of salmonids captured on the first pass by the total salmonid population estimate for that channel unit, which was approximately 0.5 for pools, 0.6 for riffles, and 0.9 for glides/runs. We then multiplied these capture efficiencies by the number of individuals of each non-salmonid species observed in different channel unit types. Error for these estimates was calculated by propagating the standard error associated with the salmonid electrofishing depletions with the variance in capture efficiency for different channel unit types (i.e., variance in capture efficiencies for riffles, runs, etc.), following standard equations for error propagation (see Taylor 1997).

In the main channel, snorkel surveys were conducted approximately monthly to estimate the abundance of larger fish (>150 mm) during 2009 and 2010. Surveys were not conducted during midwinter (December to February) and during high spring flows (April to June). Briefly, four snorkelers would float downstream over an $8-\mathrm{km}$ section of the main channel and enumerate fish by species and size class (size classes: $150-300 \mathrm{~mm}, 300-500$ $\mathrm{mm}$, and $>500 \mathrm{~mm}$ ). Error of snorkel estimates was determined by conducting three consecutive downstream surveys over a three-day period. To account for observation efficiency, we divided snorkel abundance estimates by 0.40 ; a value that was determined by tagging a small sample of whitefish $(n=30)$ with visible tags, and counting how many tagged fish were observed the following day. To estimate the abundance of juvenile salmonids $(<150 \mathrm{~mm})$, the stream margin of three 400 $800 \mathrm{~m}$ main channel segments were single-pass electrofished once in July 2009, October 2009, and March 2010. We estimated sculpin abundance in the main channel by sampling three randomly selected riffles and three runs, within which we collected three quantitative subsamples by electrofishing within the metal quadrat of the Surber sampler $\left(0.26 \mathrm{~m}^{2}\right)$. Because none of these methods were appropriate for estimating the abundance of dace, we assumed dace abundance was similar to that observed in the side channels where dace were present. We converted all fish abundance estimates to areal biomass $\left(\mathrm{g} / \mathrm{m}^{2}\right)$, by multiplying by the average mass $(\mathrm{g})$ of each species within each habitat and then dividing by habitat area $\left(\mathrm{m}^{2}\right)$. We converted wet biomass to dry mass (DM) by assuming $80 \%$ water content for juvenile fish and $75 \%$ water content for adult fish and sculpin (see Warren and Davis 1967, Elliot 1976, Berg and Bremset 1998).

We estimated annual secondary production of each fish species using the instantaneous growth rate method (Hayes et al. 2007), whereby we multiplied the average 
annual biomass of each species and age class, by size- and habitat-specific annual growth rates (or annual $P: B$ ratios). For all salmonids and suckers, growth rates were determined from recapture of marked individuals. For whitefish, we calculated size-specific growth rates from length-at-age data, which were determined by analyzing scales from approximately 80 fish (range 190$500 \mathrm{~mm}$ fork length). For sculpin, we conducted multipass electrofishing depletions within one run and one riffle in the con updwn and con dwn habitats, which allowed us to calculate production for these locations using the size-frequency method (Hayes et al. 2007). Sculpin production estimates were subsequently divided by sculpin biomass in these habitats to estimate annual $P: B$ ratios. Sculpin production in all habitat types was then calculated by multiplying $P: B$ ratios by average annual sculpin biomass. We estimated dace production by applying a $P: B$ ratio derived from the literature (Neves and Pardue 1983). Error in production estimates was calculated by propagating the standard errors associated with fish biomass and growth rate (Taylor 1997).

\section{Gut content analysis}

We collected gut content samples from all but the rarest members of the fish assemblage seasonally in the main channel and each side channel (total $n=375$ ). Diet samples for side channels were collected during electrofishing surveys. In the main channel, fish were captured for diets using a combination of techniques, including trammel and gill netting, electrofishing, and angling. At each habitat on each date, we attempted to collect at least five diet samples from all salmonid species, four from sculpin, and three from dace and juvenile suckers. We stratified steelhead sampling by age 0 and $1+$. For salmonids $>75 \mathrm{~mm}$ and for all sculpin, we collected gut contents via gastric lavage and preserved them in $70 \%$ ethanol. For dace and suckers, individuals were sacrificed, preserved in $95 \%$ ethanol, and gut contents were later extracted by removing the first $10 \%$ of the digestive tract. In the laboratory, we identified and measured the length and head width of all prey items in fish diets. Invertebrate prey items were identified to the family level and fish found in diets were identified to species. Invertebrate lengths and head widths were converted to biomass using published regressions (Benke et al. 1999). The lengths of fish found in diets were converted to biomass using lengthmass regressions developed using electrofishing data. Dietary proportions were based on the proportion that each food item contributed to total mass of gut contents. Diet proportions were averaged across all individuals of each species at each habitat on an annual basis.

\section{Trophic basis of production and flow food webs}

We quantified organic matter flows to all fish using the trophic basis of production (TBP) method, which estimates (1) contributions of different prey to fish production and (2) rates of resource consumption that support measured rates of fish production (Benke and Wallace 1980, Cross et al. 2011). The relative fraction of annual fish production attributed to each prey type $\left(F_{i}\right)$ was calculated as

$$
F_{i}=G_{i} \times \mathrm{AE}_{i} \times \mathrm{NPE}
$$

where $G_{i}$ is the proportion of prey type $i$ in fish diet, $\mathrm{AE}_{i}$ is the assimilation efficiency of prey type $i$, and NPE is the net production efficiency. For each fish species $j$, the proportion of fish production attributed to each prey type $\left(\mathrm{PF}_{i j}\right)$ was then calculated from the relative fractions $\left(F_{i}\right)$ as

$$
\mathrm{PF}_{i j}=\frac{F_{i}}{\sum_{i=1}^{n} F_{i}} .
$$

Last, annual flows from each prey type $i$ to fish consumer $j\left(\mathrm{FC}_{i j}\right.$ measured in $\left.\mathrm{g} \mathrm{DM} \cdot \mathrm{m}^{-2} \cdot \mathrm{yr}^{-1}\right)$ were calculated as

$$
\mathrm{FC}_{i j}=\frac{\mathrm{PF}_{i j} \times P_{j}}{\mathrm{AE}_{i} \times \mathrm{NPE}}
$$

where $P_{j}$ is the annual secondary production ( $\mathrm{g}$ $\mathrm{DM} \cdot \mathrm{m}^{-2} \cdot \mathrm{yr}^{-1}$ ) of fish $j$.

We used the following assimilation efficiencies for all salmonid species: 0.75 for aquatic invertebrates, 0.70 for terrestrial invertebrates, and 0.95 for fish tissue (see Warren and Davis 1967, Warren 1971, Brocksen and Bugge 1974, Elliot 1976). Diets of non-salmonids consisted almost entirely of aquatic invertebrates and assimilation efficiencies were set at 0.90 for dace, 0.85 for sucker, and 0.82 for sculpin (see Davis and Warren 1965, Atmar and Stewart 1972, Eiriksdottir 1974). Net production efficiency values were set at 0.125 for adult fish (bull and cutthroat trout, steelhead, and whitefish), whereas a production efficiency of 0.250 was used for juvenile salmonids $(<150 \mathrm{~mm})$ and all non-salmonid species (Cross et al. 2011, Donner 2011). We applied different net production efficiencies for juvenile and adult fish to account for the allometric relationship between fish consumption and growth with fish size (i.e., larger, older fish spend proportionately more energy on maintenance than on growth). A previous study on rainbow trout (Donner 2011) found that this coarse adjustment in production efficiency was adequate to generate estimates that were comparable to a more highly parameterized Wisconsin type (Hanson 1997) bioenergetics model. Although assimilation and production efficiencies might also vary with temperature, we assumed that differences in fish production across habitat types, and the uncertainty associated with these estimates, would outweigh any relatively small differences in assimilation and production efficiencies. 


\section{Interaction strength, interspecific competition, and carrying capacity}

The potential strengths of interactions between fish predators and each invertebrate prey $i$ were calculated as (Woodward et al. 2005, Benke 2011)

$$
I_{i}=\frac{\mathrm{FC}_{i}}{\mathrm{PP}_{i}}
$$

where $\mathrm{FC}_{i}$ is the total annual consumption of prey type $i$ $\left(\mathrm{g} \mathrm{DM} \cdot \mathrm{m}^{-2} \cdot \mathrm{yr}^{-1}\right)$ by the fish assemblage, and PP is the annual production of prey type $i$. This metric, hereafter termed "interaction strength," is a unitless value, ranging from 0 to 1 , which represents the proportion of annual prey-specific production consumed by the fish assemblage. Values greater than 1 (i.e., the fish assemblage is consuming more than is being produced) are energetically impossible, and indicate potential errors in our estimates of invertebrate production, fish production, and/or fish dietary proportions. In our results, however, values $>1$ were simply reported as 1 (i.e., prey production $=$ consumption). In a few cases, it appeared that discrepancies between production and demand were the result of dietary proportions skewed by individual fish that may have been feeding outside of our study habitats. These individuals were identified by diet compositions dominated by prey taxa that appeared to be rare or absent at the location where they were sampled. In total, we identified only three of these individuals, which we removed from the analysis. Although individual fish may accrue production outside of the habitats where they were sampled, we assumed that this was balanced by fish movement and foraging both inside and outside of each habitat.

To evaluate potential for exploitative competition for prey between each fish species $j$ and the rest of the fish assemblage $h$, we calculated competition coefficients (CC) as

$$
\mathrm{CC}_{j}=\sum_{i=1}^{n} \frac{\mathrm{FC}_{i h}}{\mathrm{PP}_{i}} \times \mathrm{PF}_{i j}
$$

where $\mathrm{FC}_{i h}$ is the total annual consumption of prey type $i\left(\mathrm{~g} \mathrm{DM} \cdot \mathrm{m}^{-2} \cdot \mathrm{yr}^{-1}\right)$ by all members of the fish assemblage except for the species of interest $j$, and $\mathrm{PF}_{i j}$ is the proportion of annual production for species $j$ derived from prey item $i$. This index incorporates both the availability of each prey type in the environment, after consumption by the rest of the fish assemblage $h$, and the importance of each prey item to the production of fish species $j$. The output of this index is a unitless value ranging from 0 to 1 that represents the proportion of prey items important to the species of interest $j$ that are consumed by all other members of the fish assemblage (h).

Finally, we estimated the potential level of juvenile chinook and steelhead production $\left(\mathrm{g} \mathrm{DM} \cdot \mathrm{m}^{-2} \cdot \mathrm{yr}^{-1}\right)$ that could be sustained (PotenP) per area within each habitat, which we considered an estimate of carrying capacity with respect to food resources. This was calculated as

$$
\text { PotenP } \mathrm{P}_{j}=\sum_{i=1}^{n}\left(\left(\mathrm{PP}_{i}-\mathrm{FC}_{i h}\right) \times \mathrm{AE}_{i j} \times \mathrm{NPE}_{j} \times \mathrm{PF}_{i j}\right)
$$

where $\mathrm{AE}_{i j}$ and $\mathrm{NPE}_{j}$ are assimilation and net production efficiencies for prey type $i$ by fish $j$ (i.e., juvenile chinook or steelhead). This metric assumes (1) that production by all other members of the fish assemblage does not change, (2) that the dietary proportions of all members of fish assemblage (including chinook and steelhead) remain static, and (3) that chinook and steelhead are able to perfectly track the production of their prey. Although these assumptions may not be realistic in all cases, these assumptions were imperative for deriving relative per-square-meter estimates of carrying capacity for juvenile chinook and steelhead in terms of food. Assessing carrying capacity estimates for the entire river segment would simply require scaling these per-square-meter estimates by the area of different aquatic habitat types within the floodplain. However, at the time of this study, the habitat information necessary to conduct this additional analysis was not available.

\section{Statistical analyses}

To evaluate differences in prey production vs. fish demand, we visually compared $95 \%$ confidence intervals (Huryn 1996, 1998, Cross et al. 2011). Means with nonoverlapping confidence intervals were interpreted as significantly different. We analyzed trophic basis of production data via nonmetric multidimensional scaling (NMDS), followed by multiresponse permutation procedures (MRPP) to test for differences in TBP among different habitats and species (Mielke and Berry 2001). In addition, we utilized permutation-based nonparametric MANOVAs to evaluate the amount of variation in TBP explained by both habitat type and species (Anderson 2001). Simple linear regression was conducted to explore potential relationships between water temperature, and the production, biomass and growth of key invertebrate and fish taxa. However, we could only conduct this analysis using summer water temperature data, because we lacked temperature data for all habitats during the fall, winter, and spring (see Table 1).

\section{Results}

\section{Fish production, prey production, and total consumption by fishes}

Total estimated fish assemblage production in the main channel was $1.38 \mathrm{~g} \mathrm{DM} \cdot \mathrm{m}^{-2} \cdot \mathrm{yr}^{-1}$, and was consistently greater than fish production on a per-area basis in side channels, which ranged from 0.11 to $0.63 \mathrm{~g} \mathrm{DM} \cdot \mathrm{m}^{-2} \cdot \mathrm{yr}^{-1}$ (Fig. 2A). Approximately $95 \%$ of the production in the main channel was by sculpin and whitefish. The composition of fish production varied greatly among side channels that differed in connectivity with the main channel. In the three side channels that were disconnected 

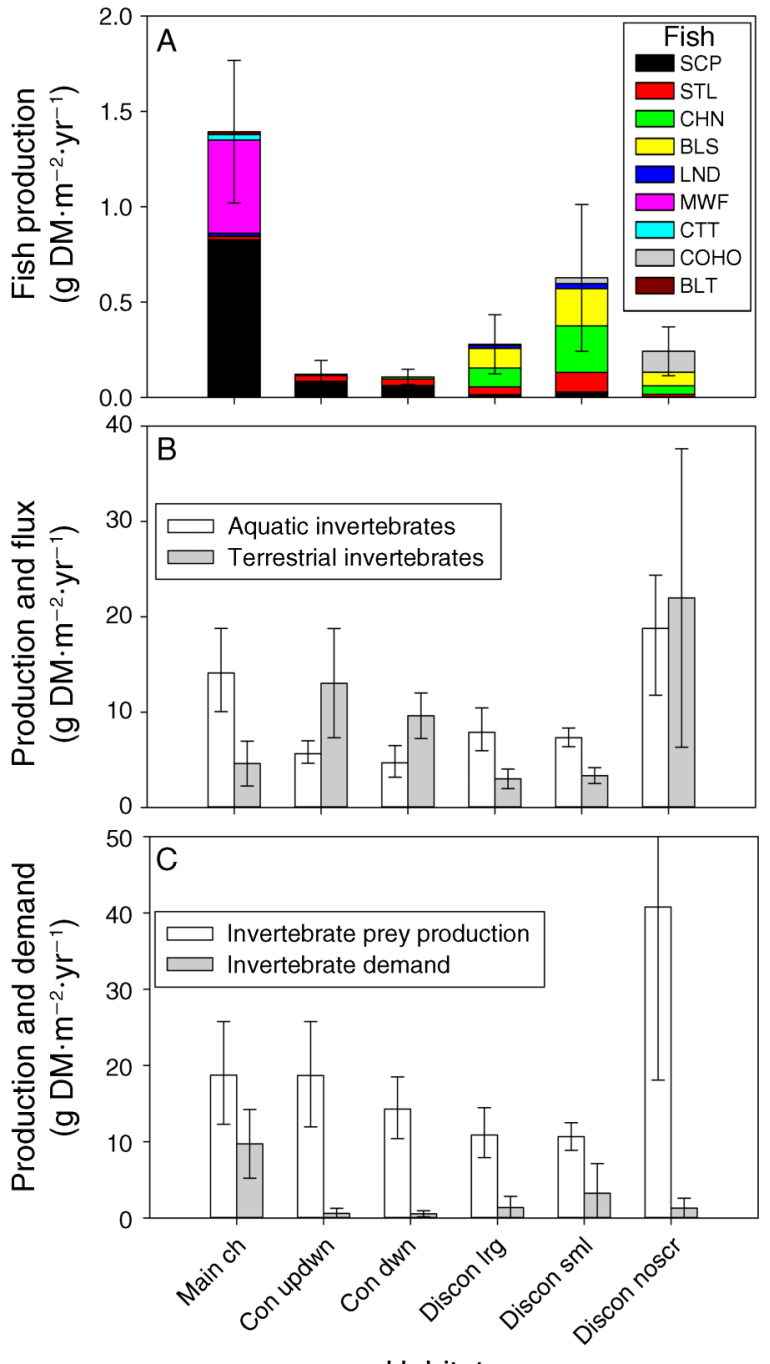

Habitat

FIG. 2. Per-area estimates of (A) fish production by species (mean $\pm \mathrm{SE}$ ); (B) aquatic invertebrate production and terrestrial invertebrate flux to aquatic habitats, with $95 \%$ confidence intervals; and (C) comparisons of total invertebrate prey production (aquatic and terrestrial contributions) to invertebrate prey demand by the entire fish assemblage with $95 \%$ confidence intervals for the main channel and each side channel in 2009-2010. The abbreviation DM stands for dry mass. Fish name abbreviations are SCP, sculpin; STL, steelhead; CHN, chinook; BLS, bridgelip sucker; LND, dace; MWF, whitefish; CTT, cutthroat; COHO, coho salmon; BLT, bull trout.

from the main channel at low flow, a larger number of species contributed more evenly to total fish production, with $52-70 \%$ being composed of salmonids, principally juvenile steelhead, along with juvenile coho and chinook salmon. On the other hand, production in the two side channels that remained connected to the main channel was dominated by sculpin. Absolute production per area by chinook and steelhead was generally highest in disconnected side channel habitats (Fig. 2A). Whitefish, cutthroat, and bull trout were rarely encountered in side channels (see Appendix B for fish abundance, biomass, and production estimates). Water temperature was not found to be significantly related to fish production, biomass, or growth, except for juvenile chinook salmon growth rate, which had a significant positive relationship with average summer water temperature $\left(R^{2}=0.73, P=\right.$ $0.03)$.

Total aquatic invertebrate production was higher in the main channel $\left(14.1 \mathrm{~g} \mathrm{DM} \cdot \mathrm{m}^{-2} \cdot \mathrm{yr}^{-1}\right)$ than most side channels $\left(4.7-18.8 \mathrm{~g} \mathrm{DM} \cdot \mathrm{m}^{-2} \cdot \mathrm{yr}^{-1}\right.$; Fig. 2B; see Appendix $\mathrm{C}$ for taxon-specific estimates of biomass, production, and $P: B)$. In contrast, the input of terrestrial invertebrates was generally higher in side channels (2.9$\left.20.8 \mathrm{~g} \mathrm{DM} \cdot \mathrm{m}^{-2} \cdot \mathrm{yr}^{-1}\right)$ than in the main channel $(4.7 \mathrm{~g}$ $\left.\mathrm{DM} \cdot \mathrm{m}^{-2} \cdot \mathrm{yr}^{-1}\right)$, but was highly variable among habitats (Fig. 2B). When terrestrial inputs were added to benthic invertebrate production, total invertebrate prey production did not significantly differ between habitats, except for in discon noscr, which had higher prey production than the two other disconnected side channels (Fig. 2C). Water temperature was not found to be significantly related to invertebrate production, biomass or $P: B$.

Demand for invertebrate prey by the fish assemblage (i.e., consumption) in the main channel was not significantly different (nonoverlapping 95\% CIs) than invertebrate production (Fig. 2C). In contrast, invertebrate production in side channels was consistently higher (on average $20 \times$ higher) than demand by the fish assemblage. In particular, the two connected side channels had over $25 \times$ more prey production than estimated fish demand.

\section{Trophic basis of production}

In the main channel, nearly $80 \%$ of the production by the entire fish assemblage was fueled by only four prey taxa: Chironomidae, Brachycentridae, Ephemerellidae, and Tipulidae (Fig. 3). In contrast, across all side channels, a comparable proportion of total fish assemblage production was fueled by at least 6 and up to 13 prey taxa (Fig. 3). The contribution of more lentic taxa (e.g., Daphnia, Amphipoda, Isopoda, Leptophlebiidae) was highest in the less connected side channels (discon $1 \mathrm{rg}$, discon sml, and discon noscr), sustaining between $16 \%$ and $71 \%$ of total fish production (see Appendix D for detailed information on prey contributions to fish diet). Total fish assemblage production in the two side channels that were more connected (con dwn and con updwn) was derived from more lotic taxa, though the contributions were more evenly distributed among prey than was the case in the main channel. Total fish production derived from terrestrial invertebrates in side channels ranged from $3.2 \%$ to $10 \%$ and was always at least double that of the main channel $(1.4 \%)$. Within each habitat, the production of different fish species was largely derived from similar prey taxa (see Appendix E for TBP figures for each fish species). In the main channel, chinook and steelhead had the most similar 


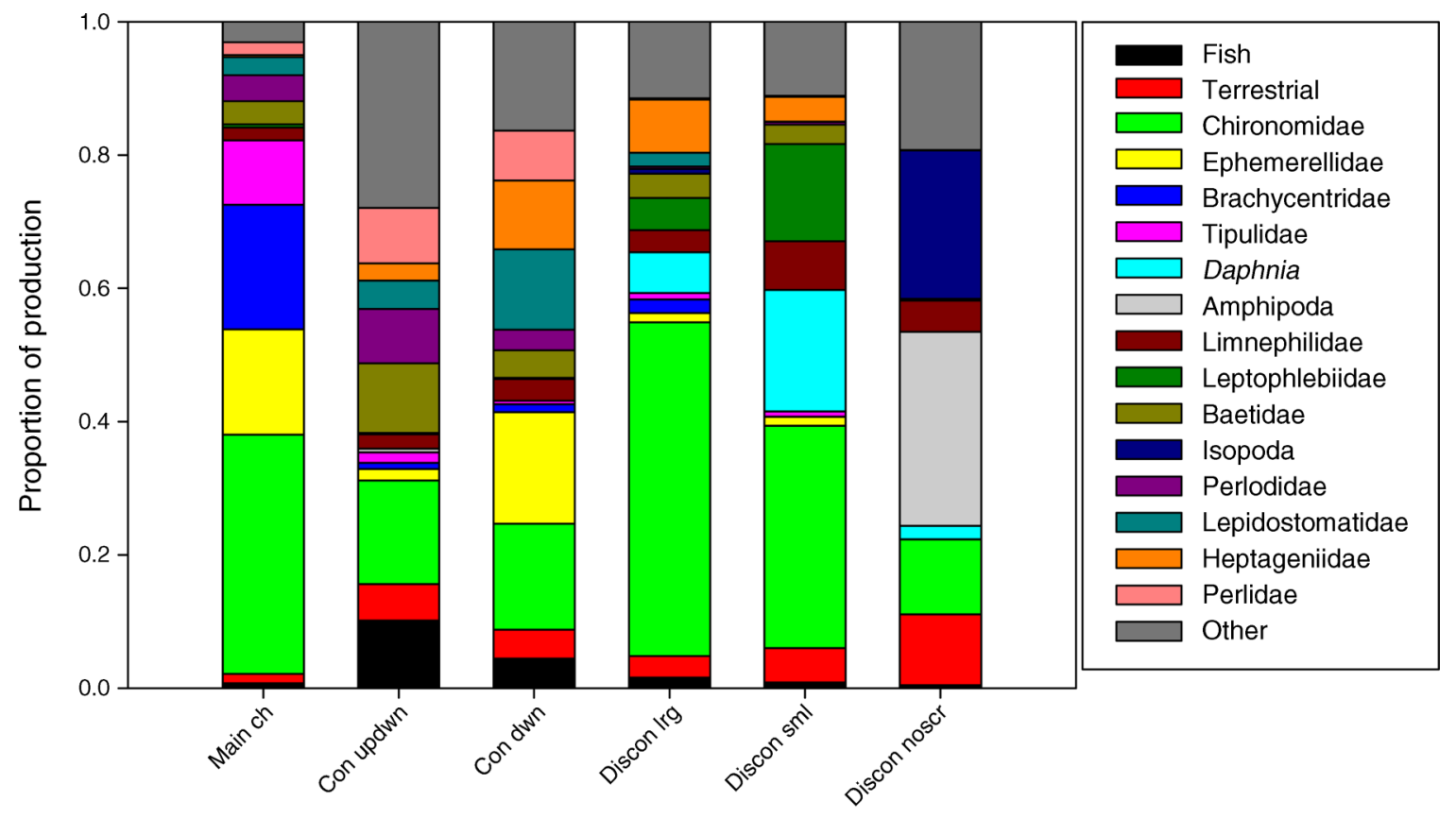

Habitat

FIG. 3. Trophic basis of production figure (Fig. 2C) that shows the proportion of total fish production in each habitat derived from different prey items during 2009-2010.

TBP. However, at least $45 \%$ of production for all fish species in the main channel, except for cutthroat and bull trout, was sustained by the same five taxa: Chironomidae, Brachycentridae, Ephemerellidae, Tipulidae, and Lepidostomatidae. In contrast, cutthroat and bull trout production was derived from much higher proportions of terrestrial invertebrates $(32 \%)$ and fish (>99\%), respectively.

In the two most connected side channels, chinook, steelhead, and sculpin all had similar TBP (see Appendix E for TBP figures for each species), although sculpin production generally lacked contributions from terrestrial invertebrates. Over $40 \%$ (and up to 67\%) of production by chinook, steelhead, and sculpin within these habitats was attributable to the same six taxa: Chironomidae, Ephemerellidae, Lepidostomatidae, Limnephilidae, Baetidae, and Heptageniidae. In the disconnected side channels that had scoured during high flows (discon lrg and discon sml), the proportion of fish production sustained by each prey item was highly variable between species. However, between $30 \%$ and up to $100 \%$ of production for each fish species was attributed to the same six prey taxa: Chironomidae, Leptophlebiidae, Daphnia, Baetidae, Limnephilidae, and Heptageniidae. In both habitats, suckers derived all of their production from only two prey taxa: Chironomidae and Daphnia. In the side channel that did not scour during high flows (discon noscr), all five fish species had very similar TBP, with at least $50 \%$ of production by each species sustained by only four prey items:
Chironomidae, Amphipoda, Isopoda, and Limnephilidae.

Variation in the composition of fish TBP among habitats reflected differences in the level of hydrologic connectivity with the main channel (Fig. 4). The NMDS ordination for each species-habitat combination, which explained $64 \%$ of the variation in TBP, showed almost complete separation between side channels connected to the main channel vs. those that were disconnected at low flow (MRPP, $A=0.145, P<0.001 ; A$ is given as a descriptor of within-group homogeneity compared to random expectation [Mielke and Berry 2001]). Connected side channels and the main channel were separated in the ordination from disconnected side channels along axis 2, which explained $32 \%$ of the variation in TBP. Although both species and habitat type were significant factors in explaining total variation in the TBP data (perMANOVA, $P<0.05$ ), habitat explained $2.5 \times$ more variation than species (35\% vs. $14 \%)$.

\section{Flow food webs}

The pathways and magnitudes of organic matter flowing between fish and their prey differed between the main channel and side channels, and also among side channels (Fig. 5). The overall magnitude of organic matter flow to the entire fish assemblage (i.e., consumption) was highest in the main channel (9.82 g $\left.\mathrm{DM} \cdot \mathrm{m}^{-2} \cdot \mathrm{yr}^{-1}\right)$ and lowest in the connected side channels (con updwn $=0.66 \mathrm{~g} \mathrm{DM} \cdot \mathrm{m}^{-2} \cdot \mathrm{yr}^{-1}$ and con $\mathrm{dwn}=0.57 \mathrm{~g}$ $\left.\mathrm{DM} \cdot \mathrm{m}^{-2} \cdot \mathrm{yr}^{-1}\right)$ reflecting differences in fish production (Fig. 2A). In the main channel, $94 \%$ of all invertebrate 


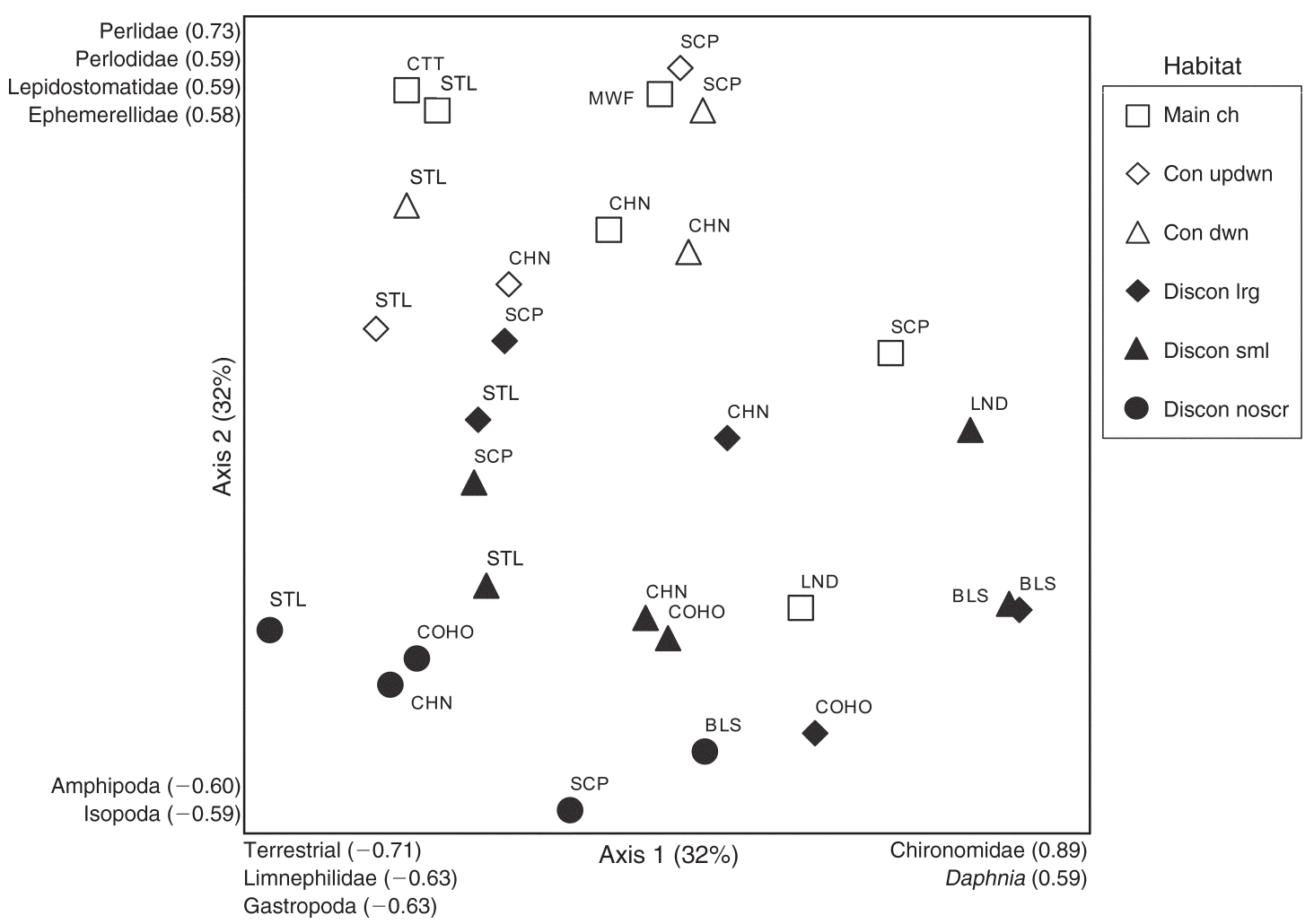

FIG. 4. Nonmetric multidimensional scaling (NMDS) ordination plots of trophic basis of production for each fish species within each habitat. Numbers in parentheses below axis titles represent the percentage of variation explained by each axis. Numbers in parentheses next to taxon names are Pearson's correlation coefficients between the taxon and the axis.

flows were to whitefish and sculpin (Fig. 5A). The highest magnitude flows in the main channel were from Brachycentridae to whitefish $\left(2.6 \mathrm{~g} \mathrm{DM} \cdot \mathrm{m}^{-2} \cdot \mathrm{yr}^{-1}\right)$, Chironomidae to sculpin (2.0) and whitefish (0.8), Ephemerellidae to sculpin (0.9), and Tipulidae to sculpin (0.62). In the two connected side channels, con updwn and con $d w n$, approximately $62 \%$ and $53 \%$ of invertebrate flows were to sculpin, respectively (Fig. 5B and C). At the con updwn side channel, the five highest magnitude flows were all to sculpin, including Limnephilidae $\left(0.8 \mathrm{~g} \mathrm{DM} \cdot \mathrm{m}^{-2} \cdot \mathrm{yr}^{-1}\right)$, Chironomidae $(0.7 \mathrm{~g}$ $\left.\mathrm{DM} \cdot \mathrm{m}^{-2} \cdot \mathrm{yr}^{-1}\right)$, Baetidae $\left(0.05 \mathrm{~g} \mathrm{DM} \cdot \mathrm{m}^{-2} \cdot \mathrm{yr}^{-1}\right)$, Perlidae (0.05 g DM $\left.\cdot \mathrm{m}^{-2} \cdot \mathrm{yr}^{-1}\right)$, and Perlodidae $(0.05 \mathrm{~g}$ $\left.\mathrm{DM} \cdot \mathrm{m}^{-2} \cdot \mathrm{yr}^{-1}\right)$. At the con $d w n$ side channel, the largest flows were from Ephemerellidae to sculpin $(0.07 \mathrm{~g}$ $\left.\mathrm{DM} \cdot \mathrm{m}^{-2} \cdot \mathrm{yr}^{-1}\right)$, Chironomidae to sculpin $(0.06 \mathrm{~g}$ $\left.\mathrm{DM} \cdot \mathrm{m}^{-2} \cdot \mathrm{yr}^{-1}\right)$, Heptageniidae to sculpin $(0.04 \mathrm{~g}$ $\left.\mathrm{DM} \cdot \mathrm{m}^{-2} \cdot \mathrm{yr}^{-1}\right)$, Lepidostomatidae to juvenile steelhead (0.04 g DM $\left.\cdot \mathrm{m}^{-2} \cdot \mathrm{yr}^{-1}\right)$, and Perlidae to sculpin (0.03 g $\left.\mathrm{DM} \cdot \mathrm{m}^{-2} \cdot \mathrm{yr}^{-1}\right)$.

Invertebrate flows in the disconnected side channels were more evenly distributed among fish species (Fig. 5D-F). In particular, flows of invertebrates to chinook were on average $19 \times$ greater, whereas flows to sculpins were $95 \%$ lower than in connected side channels and the main channel. At the discon lrg side channel, 38\% of invertebrate flow was to chinook, $37 \%$ to suckers, and
$17 \%$ to steelhead (Fig. 5D). The largest magnitude flows were Chironomidae to suckers $\left(0.43 \mathrm{~g} \mathrm{DM} \cdot \mathrm{m}^{-2} \cdot \mathrm{yr}^{-1}\right)$ and chinook $\left(0.19 \mathrm{~g} \mathrm{DM} \cdot \mathrm{m}^{-2} \cdot \mathrm{yr}^{-1}\right)$, Heptageniidae to chinook (0.10 g DM·m $\left.{ }^{-2} \cdot \mathrm{yr}^{-1}\right)$, Daphnia to suckers (0.08 $\left.\mathrm{g} \mathrm{DM} \cdot \mathrm{m}^{-2} \cdot \mathrm{yr}^{-1}\right)$, and Baetidae to chinook (0.05 g $\left.\mathrm{DM} \cdot \mathrm{m}^{-2} \cdot \mathrm{yr}^{-1}\right)$. Similar to the discon $\operatorname{lrg}$ side channel, $40 \%$ of invertebrate flows at the discon $\mathrm{sml}$ side channel were to chinook, $30 \%$ to suckers, and $18 \%$ to steelhead (Fig. 5E). The five largest magnitude flows were from Daphnia to suckers $\left(0.54 \mathrm{~g} \mathrm{DM} \cdot \mathrm{m}^{-2} \cdot \mathrm{yr}^{-1}\right)$, Chironomidae to suckers $\left(0.44 \mathrm{~g} \mathrm{DM} \cdot \mathrm{m}^{-2} \cdot \mathrm{yr}^{-1}\right)$ and chinook $(0.49$ $\left.\mathrm{g} \mathrm{DM} \cdot \mathrm{m}^{-2} \cdot \mathrm{yr}^{-1}\right)$, Leptophlebiidae to chinook $(0.30 \mathrm{~g}$ $\left.\mathrm{DM} \cdot \mathrm{m}^{-2} \cdot \mathrm{yr}^{-1}\right)$, and terrestrial invertebrates to chinook $\left(0.16 \mathrm{~g} \mathrm{DM} \cdot \mathrm{m}^{-2} \cdot \mathrm{yr}^{-1}\right)$. At the discon noscr side channel, $46 \%$ of all invertebrate flows were to coho, $28 \%$ to suckers, and $18 \%$ to chinook. The largest magnitude flows were from amphipods to coho $(0.20 \mathrm{~g}$ $\left.\mathrm{DM} \cdot \mathrm{m}^{-2} \cdot \mathrm{yr}^{-1}\right)$ and suckers $\left(0.12 \mathrm{~g} \mathrm{DM} \cdot \mathrm{m}^{-2} \cdot \mathrm{yr}^{-1}\right)$, isopods to coho $\left(0.20 \mathrm{~g} \mathrm{DM} \cdot \mathrm{m}^{-2} \cdot \mathrm{yr}^{-1}\right)$, terrestrial invertebrates to coho $\left(0.11 \mathrm{~g} \mathrm{DM} \cdot \mathrm{m}^{-2} \cdot \mathrm{yr}^{-1}\right)$, and Chironomidae to suckers $\left(0.11 \mathrm{~g} \mathrm{DM} \cdot \mathrm{m}^{-2} \cdot \mathrm{yr}^{-1}\right)$ (Fig. 5F).

A small portion of organic matter flow, generally less than $5 \%$ within each habitat, occurred along piscivorous pathways (Fig. 5). The largest magnitude piscivorous fluxes were consumption of steelhead by sculpin at con updwn, the consumption of sculpin by other sculpin at 


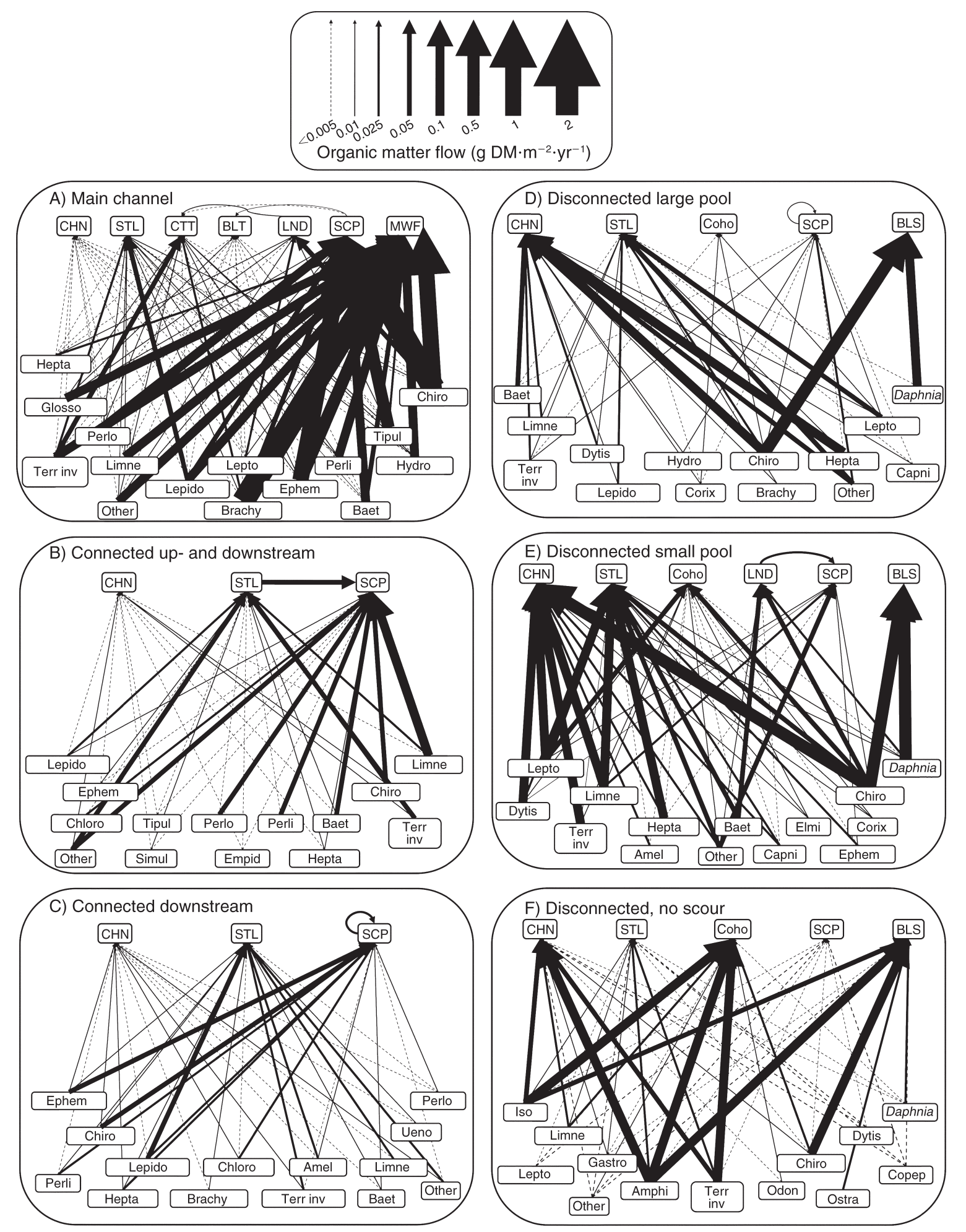

FIG. 5. Annual organic matter flows to fish consumers (i.e., consumption in $\mathrm{g} \mathrm{DM} \cdot \mathrm{m}^{-2} \cdot \mathrm{yr}^{-1}$ ) in (A) the main channel Methow and (B-F) side channels for 2009-2010. Arrow widths represent the magnitude of flows from prey to fish consumers (see key). Fish name abbreviations are as in Fig. 2. Taxon abbreviations are: Amphi, Amphipoda; Amel, Ameletidae; Baet, Baetidae; Brachy, Brachycentridae; Capni, Capniidae; Chiro, Chironomidae; Chloro, Chloroperlidae; Copep, Copepoda; Corix, Corixidae; Dytis, Dytiscidae; Elmi, Elmidae; Empid, Empididae; Ephem, Ephemerellidae; Gastro, Gastropoda; Glosso, Glossosomatidae; Hepta, Heptageniidae; Hydro, Hydopsychidae; Iso, Isopoda; Lepido, Lepidostomatidae; Lepto, Leptophlebiidae; Limne, Limnephilidae; Odon, Odonata; Ostra, Ostracoda; Perli, Perlidae; Perlo, Perlodidae; Simul, Simulidae; Terr inv, terrestrial invertebrates; Tipul, Tipulidae; Ueno, Uenoidae. 
con $d w n$, and consumption of dace by cutthroat in the main channel. Although bull trout in the main channel consumed nearly $100 \%$ fish (see Appendix B for TBP figures for each species), their production and associated food demand was small (Fig. 2A), and as a result, the total piscivorous flux to bull trout was low (Fig. 5A).

\section{Interaction strength, competition coefficients, and carrying capacity}

Estimates of the proportion of taxa-specific prey production consumed by the entire fish assemblage revealed that fish interacted more strongly with their prey in the main channel than in any of the side channels (Fig. 6, left panel). Of the top 15 prey taxa consumed by fish in the main channel, nine had interaction strengths $\geq 0.9$, indicating that the fish assemblage consumed a majority of production of those prey (Fig. 6A; see Appendix $\mathrm{C}$ for taxon-specific estimates of invertebrate production). In contrast, the two connected side channels combined had only one interaction strength that was $\geq 0.9$ (Fig. $6 \mathrm{~B}$ and $\mathrm{C}$ ). The number of interactions $>0.9$ in the three disconnected side channels ranged from a high of 6 in discon sml to 0 in discon noscr (Fig. 6D-F).

Competition coefficients, which represented the proportion of prey important to the TBP of a selected fish species that was consumed by other members of the fish assemblage, reflected general differences in interaction strengths among habitats (Fig. 6, right panel). In general, fish in the main channel had the highest competition coefficients, ranging from 0.21 for whitefish to 0.60 for dace (Fig. 6A). Connected side channels had the lowest values, ranging from: 0.05 for sculpin to 0.09 for steelhead in con updwn, and 0.07 for sculpin to 0.12 for chinook in con dwn (Fig. 6B and C). Disconnected side channels had values intermediate to those in the main channel and connected side channels, ranging from 0.08 for sucker to 0.20 for steelhead and coho in discon $\mathrm{lrg}$; 0.7 for sucker to 0.55 for steelhead in discon sml; and 0.05 for suckers to 0.15 for sculpin in discon noscr (Fig. 6D-F).

Based on our estimates of existing food resources, the potential amount of chinook and steelhead production that could be supported on a per-area basis in each habitat was on average $25 \times$ higher than measured production levels for chinook and $15 \times$ greater for steelhead (Fig. 7). However, within the discon lrg and discon sml side channels, both juvenile chinook and steelhead appeared to be at or approaching estimated carrying capacity. In the discon sml side channel, measured steelhead production was actually slightly above estimated carrying capacity, which is energetically impossible. This finding likely reflects error in our estimates of both measured fish production and modeled carrying capacity. We estimated that the highest levels of fish production could be supported in discon noscr for steelhead (0.94 $\left.\mathrm{g} \mathrm{DM} \cdot \mathrm{m}^{-2} \cdot \mathrm{yr}^{-1}\right)$ and chinook (0.98 g $\left.\mathrm{DM} \cdot \mathrm{m}^{-2} \cdot \mathrm{yr}^{-1}\right)$, followed by the con updwn side channel
(Fig. 7). The lowest carrying capacities values were found in the main channel for chinook (0.16), and the discon $\mathrm{sml}$ side channel for steelhead (0.06).

\section{Discussion}

Consistent with the paradigm that floodplains are hotspots of biophysical complexity (Junk et al. 1989, Bayley 1995, Stanford et al. 2005), our findings show that floodplains can also be hotspots of food web complexity. Food web variability in the Methow River floodplain paralleled the diversity of different habitats within the floodplain landscape. In particular, variation in hydrologic connectivity between the main channel and different side channels appeared to be associated with distinct food web structures. Chinook salmon and steelhead utilized all of these habitats, indicating that these species are flexible enough to exploit a wide range of food resources across a variety of habitats. This flexibility may be particularly important in the Methow River, as fish species that are not the focus of restoration (i.e., mountain whitefish and sculpin) dominated prey consumption in the main channel, resulting in potentially strong competition for food. However, carrying capacity estimates for both the main channel and side channels suggest that chinook salmon and steelhead are currently under-seeded with respect to the available prey base. If true, this finding would indicate that the floodplain segment of the Methow River studied here could potentially support much greater anadromous salmonid populations. Overall, these findings illustrate that habitat complexity, such as that found in floodplain landscapes, may be important to sustaining salmon and steelhead populations, and that restoration aimed at preserving and restoring the processes (i.e., large wood recruitment, cut and fill alluviation, and so on) that create and maintain this complexity may be appropriate in the Methow River.

By applying our approach across multiple habitats within a complex floodplain landscape, we observed substantial variation in food web structure (i.e., the organic matter flows). Differences in food web structure (i.e., the direction and magnitude of organic matter flows) among floodplain habitats were primarily driven by differences in fish assemblage composition and production. For example, habitats with the highest magnitude organic matter flows (i.e., consumption) also had the highest levels of total fish production. In particular, the distribution and abundance of whitefish and sculpin strongly controlled organic matter flow. Sculpin were the most productive fish species in both the main channel and connected side channels and dominated organic matter flows in these habitats. In contrast, sculpin were much less productive in disconnected habitats, and hence their consumption represented only a small proportion of total organic matter flows. Similar to sculpin, whitefish were also very abundant in main channel habitats but were virtually absent from side channels, which is not surprising given their propensity 

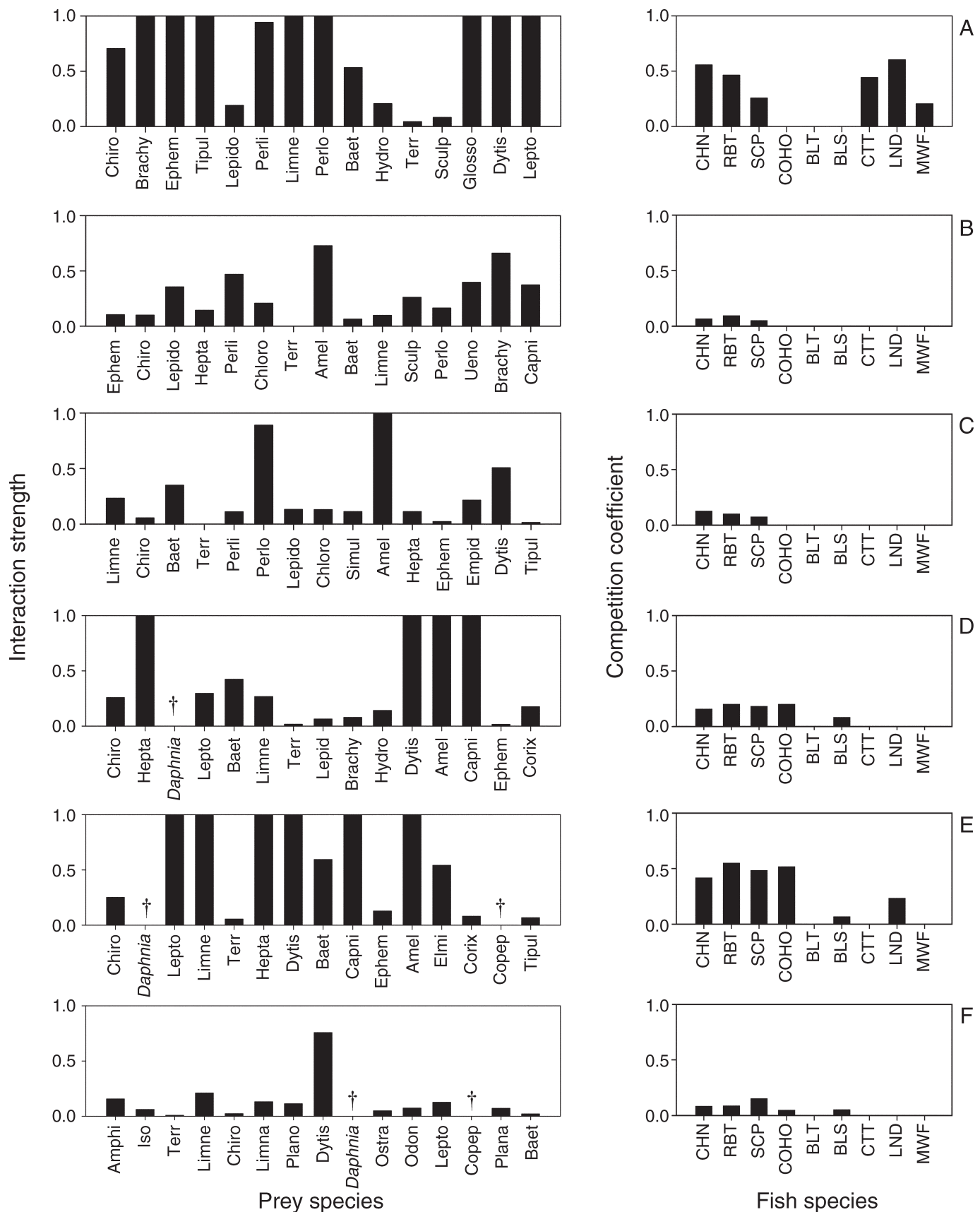

Fish species

FIG. 6. Interactions strengths for the top 15 prey items consumed by fish (left column) and competition coefficients for fish species (right column) in 2009-2010 for (A) the main channel Methow River and each side channel: (B) Con updwn, (C) Con dwn, (D) Discon lrg, (E) Discon sml, and (E) Discon noscr. See Methods: Interaction strength, interspecific competition, and carrying capacity for further description of interaction strengths and competition coefficients. Daggers $(\dagger)$ demark interaction strengths that we were not able to calculate due to unknown prey taxa production. Fish name abbreviations are as in Fig. 2. Prey species abbreviations are as in Fig. 5, and: Plana, Planaraidae; Plano, Planorbidae; Limna, Limnaeidae; Sculp, sculpins; Terr, terrestrial invertebrates.

for larger streams and rivers (Northcote and Ennis 1994). The Methow is not unique with respect to high production of sculpin and whitefish. In fact, these and other non-salmonid species are common, and often highly abundant, throughout much of the range occupied by salmon and steelhead (Wydoski and Whitney 2003, Lance and Baxter 2011). However, relatively little work has been conducted on their trophic ecology or their potential interactions within riverine food webs. 


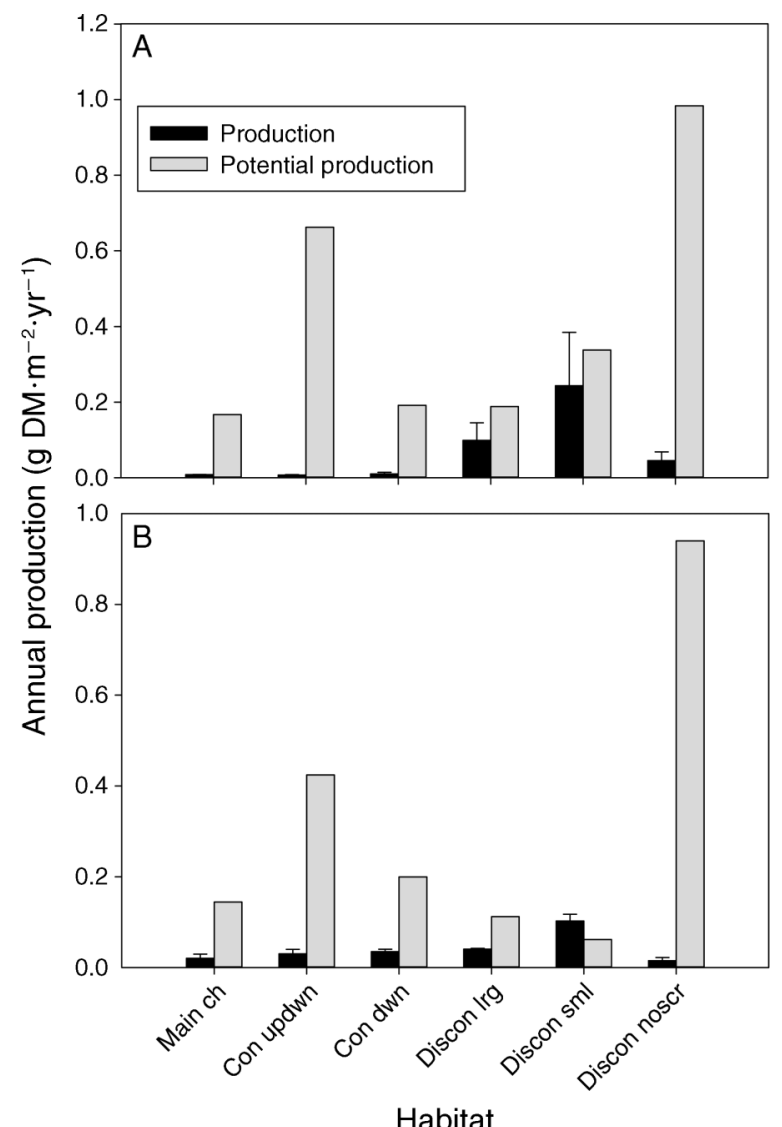

FIG. 7. Measured annual production and potential annual production for (A) juvenile chinook salmon and (B) juvenile steelhead for the main channel and each side channel in 20092010, based on available food resources. Error bars represent $95 \%$ confidence intervals.

The degree of potential exploitative competition between target and non-target fishes for food was dependent on the demand for shared prey items and the productivity of those prey items in the environment. For instance, even though sculpin dominated organic matter flows in the two connected side channels, their estimated impact on anadromous salmonids via exploitative competition was low because production for shared prey items was generally well above consumption. As a result, potential competition for food (i.e., competition coefficients), or the proportion of prey items important to chinook or steelhead consumed by other species, was low. In the main channel, however, sculpin and whitefish consumed a majority of the prey base, resulting in much higher levels of potential exploitative competition with chinook and steelhead. In disconnected side channels, non-target fish production was low and competition for food was generally intermediate between the main channel and connected side channels, and was largely attributable to competition between chinook and steelhead. These findings highlight the need for improved estimates of production by species like whitefish and sculpin. However, given the magnitude of these species role and the estimated differences between main vs. side channels, we expect our basic findings would be robust to the addition of such information.

Although numerous competition coefficients have been developed over the last several decades (e.g., MacArthur and Levins 1964, Schoener 1974), to our knowledge, this is the first time that potential for interspecific competition has been calculated in terms of the proportion $(0-1)$ of prey production important to a species of interest that is consumed by another species, or in this case, all other members of the fish assemblage. Given the simplicity of the calculation (see Methods: Interaction strength, interspecific competition, and carrying capacity), it may be that competition has not been calculated in this way before because it requires estimates of both predator and prey production, which are rarely available. Whatever the case may be, this technique could be useful for estimating potential exploitative competition among numerous types of organisms in both aquatic and terrestrial environments. Reciprocally, this approach also allowed us to determine the amount of prey production important to a species of interest that was not consumed by other species, information that we used to calculate energetic carrying capacities (potential production) for chinook and steelhead habitats.

Our estimates of the carrying capacity of different floodplain habitats to sustain juvenile chinook salmon and steelhead production varied over one order of magnitude. In the main channel, where production and food consumption by sculpin and whitefish was high, fewer resources were available to support chinook salmon and steelhead, and as a result, carrying capacity values per unit area of aquatic habitat were generally lower than found in side channels. In contrast, nontarget fish production was much lower in side channels, and as a result, we estimated that side channels generally had higher per-unit-area carrying capacities than the main channel. Overall, however, our findings indicate that juvenile anadromous fishes were generally underseeded with respect to these energetic carrying capacities, in both the main channel and side channels. In a separate study, similar results were observed within other salmon-bearing tributaries of the Columbia Basin (Bellmore et al. 2012). These findings could mean that much higher chinook and steelhead production could be supported with minimal density-dependent affects (i.e., growth, condition, and survival) on individuals.

In contrast to observed differences in carrying capacity, gross prey production was relatively consistent among side channels and also between side channels and the main channel. This finding contrasts to empirical reports (e.g., Bayley 1988, Lewis et al. 2001) and conceptual models (e.g., Junk et al. 1989) of floodplain systems, which have frequently emphasized the disproportionate importance of side channel to overall 


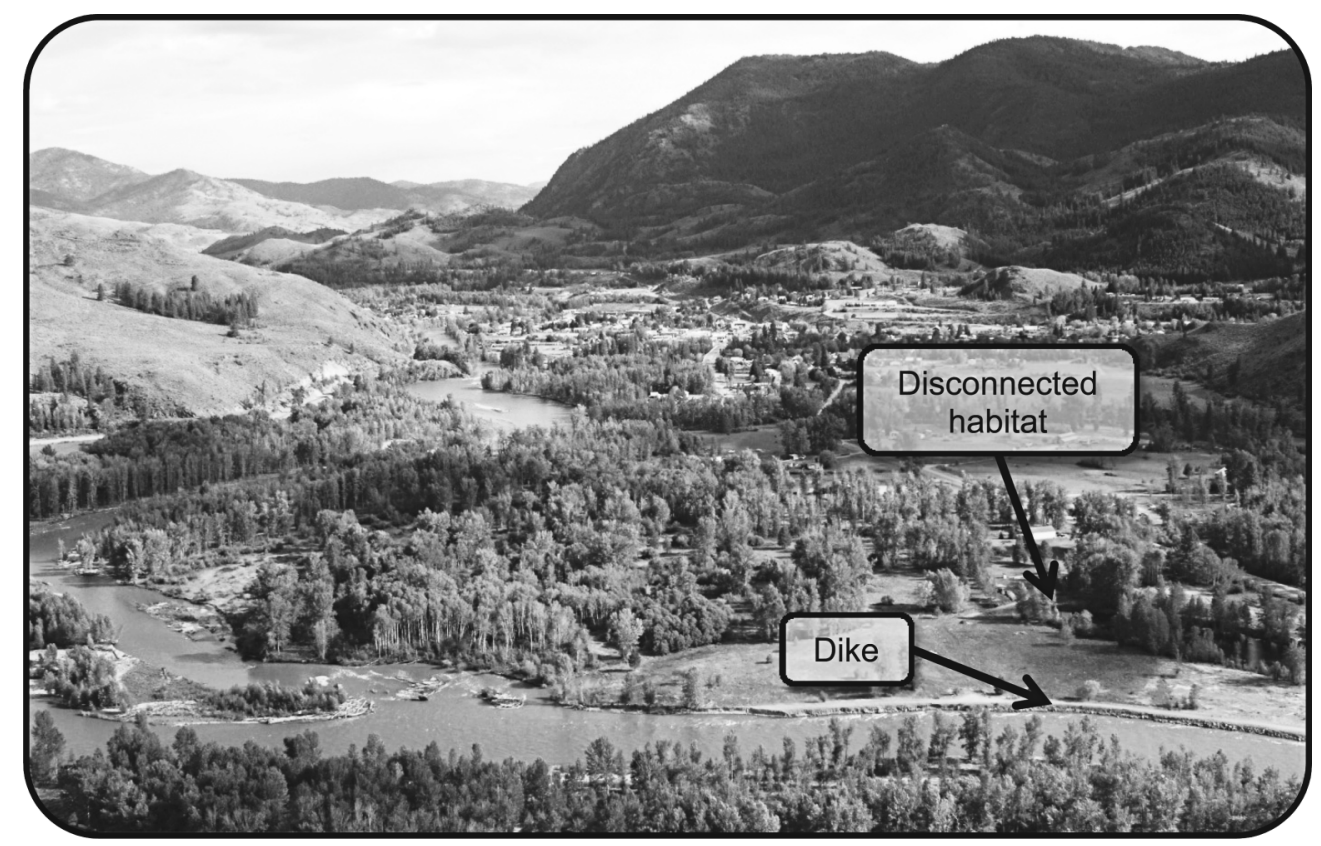

Plate 1. Aerial photograph of a floodplain segment in the Methow River (Washington, USA) during high flows in May 2008. Although large portions of the floodplain remain relatively intact, portions of the habitat mosaic have been disconnected from the main channel by diking, as shown here, and thus this segment is the site of proposed habitat restoration. A color version of this plate is available in Appendix F. Photo credit: David Walsh, Bureau of Reclamation.

floodplain productivity. One explanation for this inconsistency may be that the Methow River is much smaller and has different hydrologic characteristics compared to the larger tropical (e.g., Amazon and Orinoco Rivers) and temperate (e.g., Mississippi River) rivers where much floodplain research has been conducted. Nevertheless, in large part due to this body of research, it is often assumed that side channels utilized by salmonids have enhanced food base productivity and therefore are more favorable rearing habitats for these fish. However, this assumption has never been adequately tested in salmon bearing streams. Although a few studies have calculated the density or standing crop biomass of the food base in these side channels (e.g., Morley et al. 2005), this is the first study to undertake the additional efforts necessary to calculate annual food base productivity (i.e., secondary invertebrate production and terrestrial invertebrate fluxes), which are a necessary component of ecosystem-based energetic approaches (Odum and Barrett 2005). In fact, utilizing biomass or standing crop estimates in energetic analyses can produce paradoxical results (i.e., Allen's paradox; Hynes 1970, Waters 1988), whereby the amount of production at one trophic level is insufficient to support observed consumption at higher trophic levels (Allen 1951). That said, this study did not include estimates of invertebrate production available in the drift. Given that salmonids, such as juvenile chinook and steelhead, are considered to be primarily drift feeders (Zaroban et al. 1999), understanding how benthic production and invertebrate drift are correlated would be useful in some contexts. In our study, however, drift measurements were impractical because three of the side channels had no measureable water velocity for a majority of the year. Moreover, invertebrate drift is notoriously variable (Brittain and Eikeland 1988), such that the approaches taken (e.g., infrequent measures in space and time that are then broadly extrapolated) can result in estimates that are likely to be unreliable as absolute (vs. relative) measures of food availability.

Although we observed similar production of invertebrate prey among habitats, the composition of invertebrates that fueled the TBP (trophic basis of production) of the fish assemblage was highly variable among habitats and appeared to be associated with differences in hydrologic connectivity. In fact, differences in TBP were much greater between different habitats, than between different fish species. In particular, as side channels became more disconnected from the main channel, fish TBP was comprised of more lentic type invertebrate taxa. This finding parallels results of many studies that have shown significant variation in aquatic invertebrate assemblages across floodplain landscapes (e.g., Arscott et al. 2005). In addition, this result indicates that fish species in the Methow River, especially juvenile chinook salmon and steelhead, are flexible enough to exploit different types of prey resources across a variety of habitat types.

Our research shows that the importance of side channels to juvenile chinook salmon and steelhead in the Methow is not necessarily a function of enhanced food base productivity within those habitats. Instead, our 
findings indicate that side channels offer reduced competition for available prey. Moreover, these habitats appear to provide refugia from larger, more piscivorous species like bull trout and cuthroat trout, which were generally absent from side channels. That said, this study was not aimed at quantifying organic matter flows along piscivorous pathways; larger sample sizes would be needed to evaluate these temporally discrete but potentially important events. Even if piscivory is lower in side channels relative to the main channel, predation along alternative pathways may be greater. Research suggests that as flows recede and habitats become shallow and isolated, the risk of predation by terrestrial predators, such as birds (e.g., herons, kingfishers, and others) and mammals, is likely to increase (Power 1987, Schlosser 1991). In contrast, the lower water velocities generally associated with isolation from the main channel might reduce energetic costs associated with swimming (Fausch 1984), and depending on the availability of food, may be beneficial to rearing salmon and trout (Rosenfeld et al. 2005). Although we were unable to detect a clear relationship between water temperature and fish/invertebrate production in this study, temperature is also likely to play a key role in the relative success of fish in different habitats. Channels with extensive hyporheic connections generally have less variable temperatures during the winter and summer (Torgersen et al. 1999, Baxter and Hauer 2000, Ebersole et al. 2003), which may be more energetically favorable for growth. Side channels with limited surface or groundwater connectivity may result in water freezing during the winter and/or exceeding critical temperatures during the summer. In addition, many side channel habitats completely disappear during low flow periods, stranding fish on the floodplain surface. Overall, this heterogeneity in food web structure and physical habitat creates a mosaic of different environmental conditions across the floodplain landscape. Consequently, choosing the best or most energetically favorable habitat would require fish being able to respond to differences and trade-offs among numerous physical and biotic variables.

Although particular habitats may be identified as favorable at any single point in time, the mosaic of different aquatic habitats and associated food web structures within floodplain systems is likely to be more important to sustaining resilient and productive populations, and the overall stability of the biotic community over longer temporal scales (Groot and Margolis 1991, McCann 2000, Hilborn et al. 2003, Bisson et al. 2009). As climate and hydrology change over shorter (e.g., El Nino/Southern Oscillation and Pacific Decadal Oscillation) and longer (e.g., climate change) time scales, the potential for different habitats across the landscape to sustain fish productivity is likely to shift. Moreover, maintaining a mosaic of habitats that encompasses distinct physical and biotic conditions may help sustain multiple salmonid life-history strategies (Groot and Margolis 1991, Reeves et al. 1995). Consequently, conserving a diverse portfolio of habitats across the floodplain landscape increases the chance that at least one habitat or life-history strategy will be favored as environmental conditions change. For example, Hilborn and others (2003) found that biophysical complexity in the Bristol Bay region of Alaska supported a wide array of sockeye salmon life histories, which helped maintain the productivity of the population, despite major changes in climate conditions. At a smaller spatial scale, the biophysical mosaic found in floodplains could serve as "nodes of resilience" for endangered species like chinook salmon and steelhead.

\section{Implications for habitat restoration in the Methow River}

Our findings show that side channels are important habitats for juvenile rearing chinook salmon and steelhead in the Methow River. In particular, chinook and steelhead rearing in side channels had lower potential exploitative competition for food with other non-target fishes (e.g., sculpin and whitefish), and as a result, side channels appeared to have a greater capacity to sustain juvenile chinook and steelhead production relative to the main channel. Although floodplain reconnection efforts often assume that creating side channels that remain fully connected to the main channel year-round would create the largest benefit for salmonids, our findings did not reveal any correlation between hydrologic connectivity and productivity. Instead, these findings suggest that habitat restoration efforts should focus on maintaining current floodplain complexity, and when and where necessary, restoring the ability of the river to create and maintain this complexity (e.g., removing dikes, restoring large woody debris dynamics [sensu Reeves et al. 1995, Ebersole et al. 2003, Stanford et al. 2005]). That said, we also present some evidence that existing floodplain habitats may be substantially under-seeded with juvenile chinook salmon and steelhead, which might indicate that insufficient numbers of spawning adults are returning to fully utilize available food production.

This study presents an example of how quantitative ecosystem and food web approaches can be combined to address problems of direct relevance to natural resource management. This combined approach allowed us to quantify (1) primary organic matter flow pathways that sustain fish production, (2) prey-specific food limitation, and (3) potential competition for food. Our findings demonstrate that the pathways of organic matter flow that sustain chinook salmon and steelhead are widely variable among habitats, and that fish species that are not the target of restoration can have an overwhelming influence on organic matter flows; a finding that calls into question the validity of assessments focused on single species alone. Overall, this study demonstrates that landscape heterogeneity is associated with the occurrence of a mosaic of food webs in river floodplain systems, all of which are utilized by salmon and steelhead, and all of which maybe important to their 
recovery and long-term persistence. Future investigations are needed to quantify the basal organic matter sources (i.e., primary producers) that are the primary food for invertebrate prey, and organic matter flows along piscivorous pathways. Together, this information would provide the basis for conducting food web modeling that could be used to evaluate the implications of alternative management scenarios (e.g., habitat restoration, nutrient additions), species introductions, and environmental changes (e.g., climate change) on salmon and steelhead populations in this and other similar river systems.

\section{ACKNOWLEDGMENTS}

We are grateful to two anonymous reviewers for their comments, which improved the quality of the manuscript. Field and lab assistance provided by Dave Ayers, Jessica LuedersDumont, Wesley Tibbits, Grace Eger, Teresa Fish, Becky Hansis-O'Neill, Cameron Morris, Melinda Walker, and Rebecca Martin. We thank the members of Idaho State University Stream Ecology Center and also Michael Newsom with the Bureau of Reclamation (BOR), for insightful discussions. Funding for this project was provided by the BOR, which was administered by US Geological Survey. Additional support was provided by NSF-EPSCoR (EPS 04-47689; 08-14387).

\section{Literature Cited}

Allen, K. R. 1951. The Horokiwi Stream: a study of a trout population. New Zealand Department of Fisheries Bulletin 10.

Anderson, M. J. 2001. A new method for non-parametric multivariate analysis of variance. Austral Ecology 26:3246.

Arscott, D. B., K. Tockner, and J. V. Ward. 2005. Lateral organization of aquatic invertebrates along a corridor of a braided floodplain river. Journal of the North American Benthological Society 24:934-954.

Atmar, G. L., and K. W. Stewart. 1972. Food, feeding selectivity and ecological efficiencies of Fundulus notatus (Cyprinodontidae). American Midland Naturalist 88:7689.

Baxter, C. V., K. D. Fausch, and W. C. Saunders. 2005. Tangled webs: reciprocal flows of invertebrate prey link streams and riparian zones. Freshwater Biology 50:201-220.

Baxter, C. V., and F. R. Hauer. 2000. Geomorphology, hyporheic exchange and selection of spawning habitat by bull trout (Salvelinus confluentus). Canadian Journal of Fisheries and Aquatic Sciences 57:1470-1481.

Bayley, P. B. 1988. Factors affecting growth rates of young tropical floodplain fishes: seasonality and density-dependence. Environmental Biology of Fishes 21:127-142.

Bayley, P. B. 1995. Understanding large river-floodplain ecosystems. BioScience 45:153-158.

Beechie, T. J., E. M. Beamer, and L. Wasserman. 1994. Estimating coho salmon rearing habitat and smolt production losses in a large river basin, and implications for habitat restoration. North American Journal of Fisheries Management 14:797-811.

Beechie, T. J., P. Roni, and G. Giannico. 2008. Setting river restoration priorities: a review of approaches and a general protocol for identifying and prioritizing actions. North American Journal of Fisheries Management 28:891-905.

Bellmore, J. R., C. V. Baxter, A. M. Ray, L. Denny, K. Tardy, and E. Galloway. 2012. Assessing the potential for salmon recovery via floodplain restoration: a multitrophic level comparison of dredge-mined to reference segments. Environmental Management 49:734-750.

Benke, A. C. 2011. Secondary production, quantitative food webs, and trophic position. Nature Education Knowledge 2:2.

Benke, A. C., and A. D. Huryn. 2006. Secondary production of macroinvertebrates. Pages 691-710 in F. R. Hauer and G. A. Lamberti, editors. Methods in stream ecology. Academic Press, San Diego, California, USA.

Benke, A. C., A. D. Huryn, L. A. Smock, and B. J. Wallace. 1999. Length-mass relationships for freshwater macroinvertebrates in North America with particular reference to the Southeastern United States. Journal of the North American Benthological Society 18:308-343.

Benke, A. C., and J. B. Wallace. 1980. Trophic basis of production among net-spinning caddisflies in a southern Appalachian stream. Ecology 61:108-118.

Berg, O. K., and G. Bremset. 1998. Seasonal changes in the body composition of young riverine Atlantic salmon and brown trout. Journal of Fish Biology 52:1272-1288.

Bernhardt, E. S., et al. 2005. Synthesizing U.S. river restoration efforts. Science 308:636-637.

Bisson, P. A., J. B. Dunham, and G. H. Reeves. 2009. Freshwater ecosystems and resilience of Pacific salmon: habitat management based on natural resources. Ecology and Society 14:Article 45.

Brittain, J. E., and T. J. Eikeland. 1988. Invertebrate drift-a review. Hydrobiologia 166:77-93.

Brocksen, R. W., and J. P. Bugge. 1974. Preliminary investigations on the influence of temperature and food assimilation by rainbow trout Salmo gairdneri Richardson. Journal of Fish Biology 6:93-97.

Carpenter, S. R., J. F. Kitchell, and J. R. Hodgson. 1985. Cascading trophic interactions and lake productivity. BioScience 35:634-639.

Christensen, V., and D. Pauly, editors. 1993. Trophic models of aquatic ecosystems. ICLARM Conference Proceedings No. 26. International Center for Living Aquatic Resources Management, Manila, Philippines.

Connolly, P. J. 1996. Resident cutthroat trout in the central Coast Range of Oregon: logging effects, habitat associations, and sampling protocols. Oregon State University, Corvallis, Oregon, USA

Cross, W. F., C. V. Baxter, K. C. Donner, E. J. Rosi-Marshall, T. A. Kennedy, R. O. Hall, H. A. Wellard Kelly, and R. S. Rogers. 2011. Ecosystem ecology meets adaptive management: food web response to a controlled flood on the Colorado River, Glen Canyon. Ecological Applications 21:2016-2033.

Davis, G. E., and C. E. Warren. 1965. Trophic relations of a sculpin in laboratory stream communities. Journal of Wildlife Management 29:846-871.

Donner, K. 2011. Secondary production rates, consumption rates, and trophic basis of production of fishes in the Colorado River, Grand Canyon, Arizona: an assessment of potential competition for food. Thesis. Idaho State University, Pocatello, Idaho, USA.

Ebersole, J. L., W. J. Liss, and C. A. Frissell. 2003. Thermal heterogeneity, stream channel morphology, and salmonid abundance in northeastern Oregon streams. Canadian Journal of Fisheries and Aquatic Sciences 60:1266-1280.

Eiriksdottir, G. 1974. Feeding and assimilation by the white sucker, Catostomus commersoni. Cornell University, Ithaca, New York, USA.

Elliot, J. M. 1976. Body composition of brown trout (Salmo trutta $\mathrm{L}$.) in relation to temperature and ration size. Journal of Animal Ecology 45:273-289.

Elton, C. 1927. Animal ecology. Sidgwick and Jackson, London, UK. 
Fausch, K. D. 1984. Profitable stream positions for salmonids: relating specific growth rate to net energy gain. Canadian Journal of Zoology 62:441-451.

Gaines, W. L., C. E. Cushing, and S. D. Smith. 1992. Secondary production estimates of benthic insects in three cold desert streams. Great Basin Naturalist 52:11-24.

Groot, C., and L. Margolis. 1991. Pacific salmon life histories. University of British Columbia, Vancouver, British Columbia, Canada.

Hanson, P. C. 1997. Fish bioenergetics 3.0. University of Wisconsin, Madison, Wisconsin, USA.

Hayes, D. B., J. R. Bence, T. J. Kwak, and B. E. Thompson. 2007. Abundance, biomass, and production. Pages 327-374 in C. S. Guy and M. L. Brown, editors. Analysis and interpretation of freshwater fisheries data. American Fisheries Society, Bethesda, Maryland, USA.

Hilborn, R., T. P. Quinn, D. E. Schindler, and D. E. Rogers. 2003. Biocomplexity and fisheries sustainability. Proceedings of the National Academy of Science USA 100:65646568.

Huryn, A. D. 1990. Growth and voltinism of lotic midge larvae: patterns across an Appalachian Mountain basin. Limnology and Oceanography 35:339.

Huryn, A. D. 1996. An appraisal of the Allen paradox in a New Zealand trout stream. Limnology and Oceanography 41:243252.

Huryn, A. D. 1998. Ecosystem-level evidence for top-down and bottom-up control of production in a grassland stream ecosystem. Oecologia 115:173-183.

Hynes, H. B. N. 1970. The ecology of running waters. University of Toronto Press, Toronto, Ontario, Canada.

Isaak, D. J., and R. F. Thurow. 2006. Network-scale spatial and temporal variation in Chinook salmon (Onchorhynchus tshawytscha) redd distribution: patterns inferred from spatially continuous replicate surveys. Canadian Journal of Fisheries and Aquatic Sciences 63:285-296.

Jeffres, C. A., J. J. Opperman, and P. B. Moyle. 2008. Ephemeral floodplain habitats provide best growth conditions for juvenile Chinook salmon in a California River. Environmental Biology of Fishes 83:449-458.

Junk, W. J., P. B. Bayley, and R. E. Sparks. 1989. The flood pulse concept in river-floodplain systems. Pages 110-127 in D. P. Dodge, editor. Proceedings of the International Large River Symposium, Ottawa, Ontario. Canadian Special Publication of Fisheries and Aquatic Sciences 106.

Kohler, A. E., T. N. Pearsons, J. S. Zendt, M. G. Mesa, C. L. Johnson, and P. J. Connolly. 2012. Nutrient enrichment with salmon carcass analogs in the Columbia River Basin, USA: A stream food web analysis. Transactions of the American Fisheries Society 141:802-824.

Lance, M. J., and C. V. Baxter. 2011. Abundance, production, and tissue composition of mountain whitefish (Prosopium williamsoni) in a Central Idaho wilderness stream. Northwest Science 85:445-454.

Lewis, W. M., Jr., S. K. Hamilton, M. Rodríguez, J. F. Saunders III, and M. A. Lasi. 2001. Foodweb analysis of the Orinoco floodplain based on production estimates and stable isotope data. Journal of the North American Benthological Society 20:241-254.

MacArthur, R., and R. Levins. 1964. Competition, habitat selection, and character displacement in a patchy environment. Proceedings of the National Academy of Science USA 51:1207-1210.

McCann, K. S. 2000. The diversity-stability debate. Nature 405:228-233.

Mielke, P. W., and K. J. Berry. 2001. Permutation methods: a distance function approach. Springer series in statistics. Springer, New York, New York, USA.
Montgomery, D. R., E. M. Beamer, G. R. Pess, and T. P. Quinn. 1999. Channel type and salmonid spawning distribution and abundance. Canadian Journal of Fisheries and Aquatic Sciences 56:377-387.

Morley, S. A., P. S. Garcia, T. R. Bennett, and P. Roni. 2005. Juvenile salmonid (Oncorhynchus spp.) use of constructed and natural side channels in Pacific Northwest rivers. Canadian Journal of Fisheries and Aquatic Science 62:2811-2821.

Mullan, J. W., K. R. Williams, G. Rhodus, T. W. Hillman, and J. D. McIntyre. 1992. Production and habitat of salmonids in Mid-Columbia River tributaries. Monograph 1. U.S. Fish and Wildlife Service, Leavenworth, Washington, USA.

Neves, R. J., and G. B. Pardue. 1983. Abundance and production of fishes in a small Appalachian stream. Transactions of the American Fisheries Society 112:21-26.

Northcote, T. G., and G. L. Ennis. 1994. Mountain whitefish biology and habitat use in relation to compensation and improvement possibilities. Reviews in Fisheries Science $2: 347-371$.

NPCC. 2011. Columbia River food-webs: developing a broader scientific foundation for fish and wildlife restoration. Independent Scientific Advisory Board (ISAB) Report (ISAB 2011-1). Northwest Power and Conservation Council, Portland, Oregon, USA.

Odum, E. P., and G. W. Barrett. 2005. Fundamentals of ecology. Thomson Brooks/Cole, Belmont, California, USA.

Pikitch, E. K., et al. 2004. Ecosystem-based fishery management. Science 305:346-347.

Polis, G., M. E. Power, and G. R. Huxel, editors. 2004. Food webs at the landscape level. University of Chicago Press, Chicago, Illinois, USA.

Polis, G. A., and K. O. Winemiller. 1996. Food webs: integration of patterns and dynamics. Chapman and Hall, New York, New York, USA.

Power, M. E. 1987. Predator avoidance by grazing fishes in temperate and tropical streams: importance of stream depth and prey size. Pages 333-351 in W. C. Kerfoot and A. Sih, editors. Predation: direct and indirect impacts in aquatic communities. University Press of New England, Dartmouth, New Hampshire, USA.

Reeves, G. H., L. E. Benda, K. M. Burnett, P. A. Bisson, and J. R. Sedell. 1995. A disturbance-based ecosystem approach to maintaining and restoring freshwater habitats of evolutionarily significant units of anadromous salmonids in the Pacific Northwest. American Fisheries Society Symposium 17:334-349.

Richards, C., P. J. Cernera, M. P. Ramey, and D. W. Reiser. 1992. Development of off-channel habitats for use by juvenile Chinook salmon. North American Journal of Fisheries Management 12:721-727.

Robinson, C. T., and G. W. Minshall. 1998. Macroinvertebrate communities, secondary production, and life history patterns in two adjacent streams in Idaho, USA. Archives of Hydrobiology 142:257-281.

Roni, P., T. J. Beechie, R. E. Bilby, F. E. Leonetti, M. Pollock, and G. Pess. 2002. A review of stream restoration techniques and a hierarchical strategy for prioritizing restoration in Pacific Northwest watersheds. North American Journal of Fisheries Management 22:1-20.

Rosenfeld, J. S., T. Leiter, G. Lindner, and L. Rothman. 2005. Food availability and fish density alters habitat selection, growth, and habitat suitability curves for juvenile coho salmon (Oncorhynchus kisutch). Canadian Journal of Fisheries and Aquatic Science 62:1691-1701.

Schlosser, I. J. 1991. Stream fish ecology: a landscape perspective. BioScience 41:704-712. 
Schoener, T. W. 1974. Resource partitioning in ecological communities. Science 185:27-39.

Sommer, T. R., M. L. Nobriga, W. C. Harrel, W. Batham, and W. J. Kimmerer. 2001. Floodplain rearing of juvenile Chinook salmon: evidence of enhanced growth and survival. Canadian Journal of Fisheries and Aquatic Sciences 58:325-333.

Stanford, J. A., M. S. Lorang, and F. R. Hauer. 2005. The shifting habitat mosaic of river ecosystems. Verhandlungen der Internationalen Vereinigung für Theoretische und Angewandte Limnologie 29:123-136.

Taylor, J. R. 1997. An introduction to error analysis: the study of uncertainties in physical measurements. Second edition. University Science Books, Sausalito, California, USA.

Tockner, K., and J. Stanford. 2002. Riverine floodplains: present state and future trends. Environmental Conservation 29:308-330.

Torgersen, C. E., D. M. Price, H. W. Li, and B. A. McIntosh. 1999. Multiscale thermal refugia and stream habitat associations of chinook salmon in northeastern Oregon. Ecological Applications 9:301-319.

Vander Zanden, M. J., S. Chandra, B. C. Allen, J. E. Reuter, and C. R. Goldman. 2003. Historical food web structure and restoration of native aquatic communities in Lake Tahoe (California-Nevada) Basin. Ecosystems 6:274-288.

Vinson, M. R., and C. P. Hawkins. 1996. Effects of sampling area and subsampling procedure on comparisons of taxa richness among streams. Journal of the North American Benthological Society 15:392-399.

Walther, D. A., M. R. Whiles, M. B. Flinn, and D. W. Butler. 2006. Assemblage-level estimation of nontanypodine Chironomid growth and production in a Southern Illinois stream. Journal of the North American Benthological Society 25:444-452.

Warren, C. E. 1971. Biology and water pollution control. W. B. Saunders Company, Philadelphia, Pennsylvania, USA.
Warren, C. E., and G. E. Davis. 1967. Laboratory studies on the feeding, bioenergetics and growth of fish. Special Report 230. Pacific Cooperative Water Pollution and Fisheries Research Laboratories, Oregon State University, Corvallis, Oregon, USA.

Waters, T. F. 1988. Fish production-benthos production relationships in trout streams. Polish Archives of Hydrobiology 35:545-561.

White, G. C., D. R. Anderson, K. P. Burnham, and D. Otis. 1982. Capture-recapture and removal methods for sampling closed populations. LA-8787-NERP. Los Alamos National Laboratory, Los Alamos, New Mexico, USA.

Wiens, J. A. 2002. Riverine landscapes: taking landscape ecology into the water. Freshwater Biology 47:501-515.

Winemiller, K. O. 2005. Floodplain river food webs: generalizations and implications for fisheries management. Pages 285-312 in R. L. Welcomme and T. Petr, editors. Proceedings of the Second International Symposium on the Management of Large Rivers for Fisheries. Volume 2. Mekong River Commission, Phnom Penh, Cambodia.

Wipfli, M. S., and C. V. Baxter. 2010. Linking ecosystems, food webs, and fish production: subsidies in salmonid watersheds. Fisheries 35:373-387.

Woodward, G., and A. G. Hildrew. 2002. Food web structure in riverine landscapes. Freshwater Biology 47:777-798.

Woodward, G., D. C. Speirs, and A. G. Hildrew. 2005. Quantification and resolution of a complex, size-structured food web. Advances in Ecological Research 36:85-135.

Wydoski, R. S., and R. R. Whitney. 2003. Inland fishes of Washington. Second edition. University of Washington Press, Seattle, Washington, USA.

Zaroban, D. W., M. P. Mulvey, T. R. Maret, R. M. Hughes, and G. D. Merrit. 1999. Classification of species attributes for Pacific Northwest Freshwater Fishes. Northwest Science 73:81-93.

\section{Supplemental Material}

Appendix A

Photographs of a rip-rapped bank along main channel Methow River, Washington, USA, and the five side channels included in this study (Ecological Archives A023-013-A1).

\section{Appendix B}

Fish abundance, biomass, and production estimates within different floodplain aquatic habitats (Ecological Archives A023-013-A2).

\section{Appendix C}

Biomass, production, and P:B estimates of aquatic invertebrates within different floodplain aquatic habitats (Ecological Archives A023-013-A3).

\section{Appendix D}

Percentage of prey found in the gut contents of fish sampled within different floodplain aquatic habitats (Ecological Archives A023-013-A4).

\section{Appendix E}

The proportion of production by fish species derived from different prey items (i.e., trophic basis of production) within different floodplain aquatic habitats (Ecological Archives A023-013-A5).

\section{Appendix F}

A color version of Plate 1 (Ecological Archives A023-013-A6). 